\title{
Apuntes para una historia de la producción lexicográfica monolingüe en la Argentina: etapas del proceso de diccionarización y modalidades diccionarísticas entre 1870 y 1910
}

\author{
Daniela Lauria* \\ Universidad de Buenos Aires y Conicet, Argentina
}

\begin{abstract}
Resumen
En la Argentina, desde 1870 se inició una prolífica producción de instrumentos lexicográficos que registraban singularidades léxicas. La conciencia de tal peculiaridad condujo a confeccionar, continuando con la tradición hispanoamericana, diccionarios complementarios y contrastivos de diferentes modalidades. Por un lado, se publicaron obras descriptivas que recogían ruralismos, indigenismos, regionalismos (tanto americanismos como provincialismos o localismos) y argentinismos; por otro, algunas normativas que recolectaban barbarismos y censuraban su uso, tomando como parámetro la norma del castellano peninsular. Este artículo estudia las relaciones entre las distintas etapas del proceso de diccionarización y las diversas modalidades diccionarísticas. Para ello, analizamos los diccionarios que registran la variedad argentina del español publicados entre 1870 y 1910, atendiendo a dos aspectos: a) las
\end{abstract}

* Para correspondencia, dirigirse a: Daniela Lauria (danielalauria@gmail.com), Instituto de Lingüística, FFyL, UBA / Conicet, Defensa 1539, dpto. 15, Ciudad Autónoma de Buenos Aires, República Argentina, CP: 1143. 
diferentes condiciones del proceso de diccionarización y b) ciertos recortes seleccionados de los diversos dominios que conforman el discurso lexicográfico (paratexto, macroestructura, microestructura). De esta manera, el trabajo se propone mostrar, en primer lugar, que el diccionario monolingüe es un instrumento discursivo, histórico e ideológico. En segundo lugar, el análisis del discurso lexicográfico permite observar que dichos diccionarios operan al servicio de la construcción del imaginario nacional en el marco del proceso de formación y consolidación del Estado nacional moderno.

Palabras clave: diccionarización, modalidades diccionarísticas, discurso lexicográfico, Argentina, Estado nacional moderno, imaginario nacional.

SOME NOTES ON THE HISTORY OF MONOLINGUAL LEXICOGRAPHIC Production in Argentina: Stages of the Dictionarization PROCESS AND LEXICOGRAPHIC MODALITIES BETWEEN 1870 AND 1910.

Abstract

Since 1870, a prolific production of lexicographic instruments registering lexical singularities began in Argentina. The awareness of this peculiarity led to the elaboration -thus following a Hispanic American tradition - of complementary and contrastive dictionaries of different modalities. On the one hand, descriptive works were published that collected ruralisms, indigenisms, regionalisms (both Americanisms and provincialisms, or localisms), and Argentinianisms. On the other hand, some normative works emerged that collected barbarisms and censored their use, on account of their deviation from the peninsular Spanish variety. This paper studies the relations among the different stages of the dictionarization process and several dictionary-making modalities. To this effect, we analyze those dictionaries that included the Argentinian variety of the Spanish language, published between 1870 and 1910, by taking into account two aspects: a) the different conditions of the dictionarization process; and b) some cuts of segments selected from several domains of the lexicographical discourse (paratext, macrostructure, microstructure). First, this study intends to demonstrate that the monolingual dictionary is a discursive, historical and ideological instrument. Second, the analysis of the lexicographical discourse allows us to observe that these dictionaries operate for the construction of the national imaginary within the process of formation and consolidation of the modern national state. 
Key words: dictionarization, dictionary modalities, lexicographical discourse, Argentine, modern national state, national imaginary.

Recibido: 26/07/10.

Aceptado: 04/05/11.

\section{INTRODUCCIÓN}

En la Argentina, a partir de 1870, se inició una prolífica producción de instrumentos lexicográficos que registraban singularidades léxicas. La conciencia de tal peculiaridad condujo a confeccionar, continuando con la tradición hispanoamericana, diccionarios complementarios y contrastivos de diferentes modalidades. Por un lado, se publicaron obras descriptivas que recogían ruralismos, indigenismos y regionalismos (tanto americanismos como provincialismos o localismos). Por otro, algunas obras normativas que recolectaban barbarismos, vulgarismos y solecismos y censuraban su uso, tomando como parámetro la norma del castellano peninsular. En los primeros años del siglo xx aparecieron los diccionarios de argentinismos. Todas las formas diccionarísticas, sin excepción, siguen como criterio contrastivo de referencia el material léxico consignado en el Diccionario de la Real Academia Española (DRAE).

En este artículo examinamos puntualmente las relaciones entre las distintas etapas del proceso de diccionarización ${ }^{1}$ y las diversas modalidades diccionarísticas. Para ello, analizamos, desde el marco teórico y metodológico de la Glotopolítica (Arnoux 2000 y 2008; Arnoux y del Valle 2010 y del Valle 2007), los diccionarios que registran la variedad argentina del español publicados entre 1870 y 1910, atendiendo a dos aspectos: a) las diferentes condiciones del proceso de diccionarización; b) ciertos recortes de los dominios específicos que conforman el discurso lexicográfico: los elementos paratextuales (títulos, prólogos, notas, apéndices, etc.); la macroestructura o nomenclatura, es decir, el inventario de voces que se define

1 En el marco de la Historia de las Ideas Lingüísticas, Auroux (1992a: 65) define el concepto de gramatización como "[el] proceso que conduce a describir y a instrumentar una lengua sobre la base de dos tecnologías que son todavía hoy los pilares de nuestro saber metalingüístico: la gramática y el diccionario". El término diccionarización, por su parte, fue acuñado por el investigador brasileño Nunes (2002: 99) basándose, claro está, en el de gramatización y se entiende como: “(...) la descripción e intrumentalización de la lengua sobre la base del diccionario". En adelante, las traducciones son nuestras. 
y la microestructura, esto es, el conjunto de informaciones ordenadas que en el artículo lexicográfico siguen a la entrada (formulación de los enunciados definidores, presencia de marcas de uso, inclusión de citas y ejemplos e incorporación de observaciones etimológicas y enciclopédicas). De esta manera, el trabajo se propone mostrar, en primer lugar, que el diccionario es un instrumento discursivo, histórico e ideológico. En segundo lugar, el análisis del discurso lexicográfico permite observar que dichos diccionarios operan al servicio de la construcción del imaginario nacional en el marco del proceso de formación y consolidación del Estado nacional moderno.

\section{LA GLOTOPOLÍTICA: PRINCIPIOS TEÓRICO-METODOLÓGICOS}

Nuestro trabajo se inscribe en el campo disciplinario de la Glotopolítica. En el año 1986, los teóricos franceses Guespin y Marcellesi, fundadores de la Escuela de Rouen, acuñan el término:

[Glotopolítica] tiene la ventaja de neutralizar sin expresarse en relación a ella, la oposición entre lengua y habla. Glotopolítica designa los diferentes enfoques de una sociedad acerca de la acción sobre el lenguaje, sea esta consciente o no. Puede referirse a la lengua, cuando la sociedad legisla, por ejemplo, respecto del estatuto de distintas lenguas en contacto; al habla, cuando reprime uno u otro empleo; al discurso, cuando la escuela privilegia en los exámenes la producción de un determinado tipo de texto. Glotopolítica es un término necesario para englobar todos los hechos de lenguaje en los que la acción de la sociedad reviste la forma de lo político (Guespin y Marcellesi 1986: 5).

De acuerdo con estos autores, el campo de la Glotopolítica tiene como finalidad actuar no solo sobre el estatuto de las lenguas sino también sobre las prácticas lingüísticas, por lo que engloba, así, a la política de la lengua entendida en sentido tradicional (Calvet 1996 [1997])². Más adelante,

2 La política lingüística se define según Calvet (1996 [1997: 5]) como la “(...) determinación de las grandes opciones en materia de relaciones entre las lenguas y la sociedad (...)”. La política lingüística y la planificación [su puesta en práctica] son generalmente ejercidas por los gobiernos, de modo directo o por delegación ya que "(...) sólo el Estado tiene el poder y los medios para pasar al estadio de la planificación, poner en prácticas sus elecciones políticas" (1996 [1997: 10]). 
Guespin y Marcellesi añaden que el término Glotopolítica puede ser utilizado con dos fines: tanto para la evocación de las prácticas como para la designación del análisis; la Glotopolítica es, entonces, a la vez una práctica social y una disciplina de investigación.

En la Argentina, Arnoux (2008) define la Glotopolítica como el estudio que aborda las posiciones e intervenciones sobre el lenguaje atendiendo a la relación que éstas entablan con transformaciones socio-históricas más generales. De ese modo, se interesa por los diversos tipos de acciones en el espacio público del lenguaje llevadas a cabo ya sea desde el Estado, ya sea desde ciertos sectores de la sociedad civil. Estudia, en consecuencia, la incidencia de los procesos políticos, económicos, sociales, culturales y tecnológicos en el ámbito del lenguaje y los gestos de intervención a los que dan lugar, así como el papel de las lenguas en la construcción de las identidades colectivas como, por ejemplo, las identidades nacionales ${ }^{3}$.

Los trabajos realizados desde la perspectiva glotopolítica en la Argentina tienen una impronta histórica fuerte puesto que en sus análisis se atiende, como ya indicamos, a procesos políticos, económicos, sociales, culturales y tecnológicos. Asimismo, estos trabajos acentúan el carácter interpretativo de las investigaciones. De ahí que el enfoque glotopolítico, tal como lo plantea Arnoux (2008), se articule con la metodología del Análisis del Discurso (Arnoux 2006) como herramienta que provee la construcción de un dispositivo de análisis acorde con los materiales y a los objetivos planteados. La autora sostiene que se enfocan los textos no solo como documentos, siguiendo el camino habitual del estudio histórico de las políticas lingüísticas,

Arnoux (2008) explica que la Glotopolítica se centra en el estudio de las prácticas, de las actitudes y de las reflexiones -sistemáticas o no-sobre el lenguaje en espacios institucionales oficiales y no oficiales. Aborda tanto las intervenciones explícitas como los comportamientos espontáneos, la actividad epilingüística y las prácticas metalingüísticas. Considera distintas temporalidades como la larga duración: la conformación de los Estados nacionales (en el marco de la economía mundo occidental) y los procesos de mundialización (en el marco de la economía mundo planetaria); los tramos históricos vinculados con procesos y problemáticas regionales, nacionales, supranacionales específicos (la independencia; la inmigración; el ascenso de movimientos populares; los golpes de Estado; la formación de los bloques de integración regional) y los acontecimientos concretos (la aparición de un muevo medio de comunicación o de una nueva tecnología de la palabra, la creación de instituciones educativas y de agencias de política lingüística como, por ejemplo, las academias de la lengua; el diseño y puesta en marcha de una reforma educativa). Y trabaja con ciertos materiales del archivo histórico - próximo o distante: documentos variados (debates, polémicas, biografías, memorias, obras de ficción) a partir de los cuales se pueden indagar las prácticas lingüísticas; textos normativos (reglamentaciones, resoluciones, decretos, leyes, informes institucionales) que intervienen en el espacio de las lenguas y textos descriptivo-prescriptivos (gramáticas, diccionarios, ortografías, textos didácticos, retóricas) que regulan la actividad lingüística. 
sino que principalmente se los aborda como discursos ${ }^{4}$, lo que conduce a una actividad interpretativa que busca conjugar lenguaje e historia a partir de múltiples remisiones a las condiciones de producción ${ }^{5}$ a través del reconocimiento y de la descripción de rasgos lingüístico-discursivos que se interpretan como huellas de esos procesos históricos y que están cargados ideológicamente. En suma, los discursos producen sentidos que varían conforme las distintas coyunturas en las que fueron formulados.

Destacamos, además, otros dos aspectos de los análisis realizados desde este enfoque. Por un lado, se trata de trabajos de carácter interdisciplinario en el que se cruzan saberes provenientes de las ciencias humanas y sociales ${ }^{6}$.

4 Por discurso, entendemos, con Courtine (1981), un objeto integralmente lingüístico e integralmente histórico.

5 Desde el Análisis del Discurso, Orlandi (2000: 30) sostiene: "Podemos considerar las condiciones de producción en sentido estricto y tenemos las circunstancias de la enunciación, esto es, el contexto inmediato. Y si las consideramos en sentido amplio, las condiciones de producción incluyen el contexto socio-histórico, ideológico". Así, tomando el diccionario, tenemos dos planos de manifestación. Si consideramos las condiciones de producción en sentido estricto -quién habla, qué dice, para quién, en qué situación- vemos la posición del lexicógrafo (la figura del autor, del editor, del equipo organizador, etc.). Esto se manifiesta, por ejemplo, en los prólogos donde se construyen las imágenes de los lectores y del diccionario: el plan de la obra, la relación del diccionario con la lengua, la nomenclatura seleccionada, los procedimientos lexicográficos, el contexto en el cual se inserta, etc. Si las consideramos en sentido amplio, el análisis de la nomenclatura y de los enunciados definidores nos permite explicitar las marcas de la posición del lexicógrafo en una formación social. Dicha posición nos remite al lugar que establece lo que puede y debe ser dicho en determinadas circunstancias, y no se refiere ya a un autor empírico.

6 En nuestro caso, en particular, recurrimos a saberes provenientes de distintas áreas de la Lingüística teórica y aplicada. Destacamos el hecho de que nuestra investigación se sirve también de ciertos conceptos provenientes de otra línea teórico-metodológica, aunque sumamente complementaria: la Historia de las Ideas Lingüísticas, básicamente de las investigaciones realizadas en Francia (Auroux 1992a y b, 2007 y 2009 y Collinot y Mazière 1997) y en Brasil en su articulación con la Escuela materialista francesa del Análisis del Discurso, en particular, la línea iniciada por Pêcheux (Guimarães y Orlandi 1996; Orlandi 1998, 2001, 2002, 2007 y 2009; Nunes y Petter 2002; Orlandi y Guimarães 2002 y Nunes 2006a), que inquiere el saber sobre la lengua en relación con las políticas lingüísticas. Nociones desarrolladas desde estas tradiciones tales como gramatización, diccionarización, instrumento lingüístico, heterogeneidad lingüistica, lengua imaginaria, lengua fluida, hiperlengua, acontecimiento discursivo, acontecimiento lingüistico, colonización lingüística, entre otras, permiten explicar la relación lengua / historia social en el marco del estudio del proceso de instrumentalización de una lengua y de la constitución de una identidad nacional. En particular, los trabajos oriundos de Brasil tienen como finalidad analizar la cuestión de la lengua (la historia de la producción de ideas lingüísticas, el proceso de gramatización y de constitución de la lengua nacional, el desarrollo de conocimiento científico sobre ella y la implementación de políticas lingüísticas) en países que se desprenden de un pasado colonial y en los que, en consecuencia, se trasplantó la lengua de sus exmetrópolis, atendiendo a su propia historicidad. 
Por otro, se trata de análisis de índole cualitativa e inductiva. Esto significa que las conclusiones que se derivan del corpus examinado no se pueden extrapolar a otros materiales.

Uno de los principales ejes de los trabajos que adoptan la perspectiva glotopolítica es focalizar la relación ineludible que se entabla entre los discursos sobre el lenguaje y la construcción simbólica de las representaciones sobre la nación en el marco del proceso de conformación y consolidación de los Estados con bases nacionales. En otras palabras, dichos trabajos se interrogan acerca de cómo los Estados nacionales que se construyen, básicamente a lo largo del siglo XIX, moldean (son, en verdad, las clases dirigentes las que lo forjan) el imaginario nacional que los sostienen. Arnoux (2008) afirma que estudiar las ideas sobre la lengua y el lenguaje en la constitución y consolidación de los Estados conlleva necesariamente a indagar acerca de las concepciones sobre la nación que subyacen a esos discursos, esto es, cuáles son los contornos que definen la nación: en qué elementos reside ese imaginario, qué aspectos se seleccionan y cuáles se dejan de lado. En este sentido, el discurso lexicográfico, en tanto discurso sobre la lengua, deja entrever, en nuestra opinión, un determinado proyecto de nación. Para nosotros, la elaboración de un diccionario es un acto glotopolítico. Por un lado, porque implica tomar decisiones en torno a una serie de cuestiones tales como la unidad o la fragmentación de la lengua, la variación, la norma, el uso, la prescripción, la descripción, el cambio lingüístico, el purismo, la corrupción idiomática, el contacto de lenguas, los indigenismos, los préstamos, los neologismos, los arcaísmos, los tecnicismos, los extranjerismos, los calcos, los barbarismos, la lengua culta o literaria y la lengua popular. Y, por otro, porque no solo revela continuidades con fenómenos que pertenecen a los ámbitos político, económico, social, cultural y tecnológico de la coyuntura histórica en la que se inserta, sino porque también activa determinadas memorias. Los diccionarios constituyen, así, discursos donde se asoman y se esconden sistemas lingüístico-políticohistórico-ideológicos, que participan desde la reflexión sobre el lenguaje en la constitución del imaginario nacional.

\section{LOS DICCIONARIOS MONOLINGÜES Y LOS PROCESOS DE FORMACIÓN DE LOS ESTADOS NACIONALES}

En Europa, la producción de diccionarios monolingües -textos descriptivo-prescriptivos que regulan la actividad lingüística sobre la base 
de conceptos tales como normatividad, autoridad, legitimidad y cultura lingüística monoglósica- surgió en el siglo $\mathrm{XVI}^{7}$ y ha estado, a lo largo de la historia, fuertemente vinculada con la idea de organización y de consolidación de los Estados nacionales modernos. A propósito, Auroux (1992a) señala que las causas que generaron el saber lingüístico y que originaron la aparición de instrumentos lingüísticos fueron complejas y diversas. La aparición del diccionario monolingüe tuvo lugar durante el Renacimiento a partir de una tradición lingüística determinada (la grecolatina). Este proceso se llevó a cabo, entre otras razones, tanto por la formación de los Estados nacionales europeos como por el proceso de colonización. El autor señala entre los motivos (1992a: 29): “(...) el aparato del Estado y la administración, la expansión de una religión, la emergencia de una conciencia nacional (...), la dispersión de un pueblo, etc." ". Auroux insiste en que la atribución de una identidad nacional constituyó también un factor motivador de la producción de diccionarios, ya que en él aparecen términos vinculados con la raza, con los grupos sociales, con diversos elementos culturales. En términos similares, Lara (1997: 26) afirma que “(...) la reflexión sobre la lengua que ocurre en el siglo XVI es, claramente, una reflexión orientada y aprovechada por la política, ligada a las necesidades de los Estados nacionales nacientes".

En América, el interés por recopilar y definir lo que es peculiar del continente, de cierta región o de una nación en particular en el plano de la lengua y en especial en el componente léxico comenzó, desde luego, en las primeras décadas del siglo XIX como consecuencia del proceso emancipador (1810-1824) y de la necesidad de construir imaginarios identitarios nacionales. En Hispanoamérica se elaboraron, desde los inicios del proceso de diccionarización monolingüe, instrumentos lexicográficos de carácter complementario y contrastivo de las obras peninsulares, especialmente

Entre las principales obras están el Der betler orden de 1509, para el alemán; Tesoro de la lengua castellana o española de Sebastián Covarrubias de 1611 y el Diccionario de la lengua castellana de la Real Academia Española (RAE) de 1726 (conocido como Diccionario de autoridades), para el español; el Vocabolario degli Accademici della Crusca de 1612, para el italiano; el Thresor de la langue francoyse de Jean Nicot de 1606, el Dictionnaire de l'Académie Françoise de 1694, para el francés; el A Table Alphabeticall de Robert Cawdrey de 1604, The New English Dictionary de John Kersey de 1702 y el Dictionary of the English Language de Samuel Johnson de 1755, para el inglés y el Dicionário da Lingua Portuguesa de Antonio de Moraes Silva de 1789, para el portugués.

8 Podemos agregar también el desarrollo de una economía capitalista incipiente. 
del DRAE, esto es, diccionarios de americanismos, de provincialismos, de regionalismos, entre otros.

En la Argentina, el proceso de diccionarización monolingüe del español se inició, en términos estrictos, en la primera mitad del siglo XIX con el Vocabulario rioplatense de Francisco J. Muñiz del año $1845^{10}$. Pero fue solo a partir de 1870 y hasta el Centenario de la Revolución de Mayo (1910), en el marco del proceso de formación y consolidación institucional del Estado y de la nación moderna caracterizado por la definición y unificación territorial, la centralización y el ordenamiento administrativo y jurídico, la organización de un mercado interno, el desarrollo urbano e industrial, la promoción de la instrucción pública y la definición de la lengua común, entre otros factores, por un lado, y del comienzo del movimiento migratorio masivo que trajo aparejado un aumento de la diversidad lingüística, social y cultural con sus correlativas tensiones, por el otro, cuando se intensificaron las instancias planificadoras en el dominio simbólico del idioma con el fin de construir un espacio cultural y lingüísticamente homogéneo, que diera cuenta de la individualidad nacional.

9 Al respecto, Lara (1996: 346) sostiene: "La historia de nuestra lexicografía [hispanoamericana] consiste sobre todo en dos clases de diccionarios: por un lado, los generales, que hasta ahora se han escrito exclusivamente en España (aunque lleguen a imprimirse o a refundirse en otros países, como Argentina o México), y toman por objetivo la «totalidad» de la lengua; por el otro, los de regionalismos, que se escriben en cualquier territorio hispanohablante que no sea la metrópoli castellana (...) y que se conciben como complementos de los generales; es decir, que se dedican a documentar el vocabulario particular de cada región y solo en la medida en que no forme parte de lo que se considere lengua general". El destacado es del original. V. también Haensch (1994). Sobre este punto, sin embargo, es importante mencionar que en los últimos años se elaboraron en México tres diccionarios generales del español que se habla en ese país, bajo la dirección justamente de Luis F. Lara: Diccionario fundamental del español de México, que publicó el Fondo de Cultura Económica en 1982; el Diccionario básico del español de México, que publica desde 1986 la editorial de El Colegio de México, y el Diccionario del español usual de México de 1996, publicado también por la editorial de El Colegio de México. Se espera que el Diccionario del Español de México esté terminado en el 2010. En la Argentina, por su parte, se publicó (abril de 2009) el primer diccionario integral del español: Diccionario integral del español de la Argentina de la editorial Voz Activa.

10 Muñiz, Francisco J. (1845): Vocabulario rioplatense. En Boletín de la Academia Argentina de Letras, t. V, 1937, pp. 393-453 (edición y prólogo de Milcíades Vignati). 


\section{EL PROCESO DE FORMACIÓN Y CONSOLIDACIÓN DEL ESTADO NACIONAL ARGENTINO}

Sucintamente, podemos recordar que luego de la caída del gobernador de Buenos Aires, Juan Manuel de Rosas, en la Batalla de Caseros en 1852, los intelectuales de la organización nacional (principalmente Domingo Faustino Sarmiento y Juan Bautista Alberdi) se abocaron tanto a la tarea de reflexionar sobre la formación de las instituciones estatales como a la de definir las características que debía portar la idea de lo argentino (Halperín Donghi 1982).

De acuerdo con Oszlak (1997), fue solo a partir de 1862 (y hasta 1880) que se dio la necesidad de asegurar el orden y materializar el ideal de progreso. Para esto, se requirió la formación de un Estado fuerte y poderoso que cumpliera un papel de articulador esencial de los patrones de relación social que permitieron instituir un orden capitalista en la sociedad. Para este autor, las propiedades que debía tener el Estado nacional eran:

1. Capacidad de externalizar su poder, obteniendo reconocimiento como unidad soberana dentro de un sistema de relaciones interestatales.

2. Capacidad de institucionalizar su autoridad, imponiendo una estructura de relaciones de poder que garantizara su monopolio sobre los medios organizados de coerción.

3. Capacidad de diferenciar su control a través de la creación de un conjunto funcionalmente diferenciado de instituciones públicas con reconocida legitimidad para extraer establemente recursos de la sociedad civil, con cierto grado de profesionalización de sus funcionarios y cierta medida de control centralizado sobre sus actividades.

4. Capacidad de internalizar una identidad colectiva, mediante la emisión de símbolos que reforzaran los sentimientos de pertenencia y de solidaridad social y permitieran el control ideológico como mecanismo de dominación.

Conviene destacar que Oszlak considera que los procesos de construcción del Estado y de la nación se produjeron simultáneamente a partir de la convergencia de elementos materiales (determinación de un sistema de producción, conformación de un mercado interno y establecimiento de una estructura de clases) y abstractos (apelación a la tradición, a la lengua y a la raza en tanto factores de integración y de formación de una identidad) en oposición a lo que plantea una serie de historiadores para quienes hacia 1880 se construyó el Estado, pero no la nación. En efecto, Bertoni (2001) 
señala que la Argentina entre 1880 y el Centenario se encontraba en medio de un momento de transición, de crisis, caracterizado por el recibimiento de los contingentes inmigratorios más numerosos y, como correlato de esta situación, inmersa en un proceso inconcluso de formación de la nación y de la nacionalidad.

En definitiva, para Oszlak, este proceso se llevó a cabo a partir de cuatro modalidades de dominación: 1 . represiva; 2 . cooptativa; 3 . material y 4. ideológica. La primera se vincula particularmente con el aparato militar. A modo de ilustración, menciona las campañas de la Conquista del Desierto que se produjeron entre 1870 y 1879 . La segunda se relaciona con los pactos y las alianzas entre clases y sectores regionales (y económicos) a fin de lograr la dominación estatal. La tercera se vincula con la realización de obras y servicios públicos, principalmente el establecimiento de las redes del ferrocarril y el desarrollo urbano e industrial. La cuarta, que es la que tenemos en cuenta para nuestro trabajo, se relaciona con los mecanismos que operaron sobre las actitudes, las representaciones y las conductas, procurando un sentimiento de pertenencia a la comunidad nacional. Estas operaciones de penetración ideológica tienen que ver fundamentalmente con la producción simbólica por parte del Estado que se concretó a través de mecanismos practicados especialmente después de 1880 por un sector de la clase dirigente cuando las instituciones del Estado ya estaban, en alguna medida, consolidadas.

\section{DICCIONARIZACIÓN EN LA ARGENTINA: CONDICIONES, PROCESOS Y MODALIDADES}

El Estado en la Argentina, entonces, en el período histórico abordado (1870-1910) tuvo una incidencia social fuerte en el sentido de que llevó adelante políticas dirigistas en diversas áreas de intervención: sancionó innumerables leyes, fundó ciudades, implementó economías y también actuó en el plano simbólico forjando, por ejemplo, una identidad nacional desde el aparato escolar. En esta línea de interpretación, nuestro punto de partida es que los diccionarios que registran la variedad argentina del español publicados entre 1870 y 1910 operan como instrumentos al servicio de la construcción de la nación. Postulamos, en consecuencia, que la elaboración de dichos diccionarios es un gesto de codificación y, por lo tanto, de intervención en el espacio de la lengua por parte del Estado (o de miembros de sectores de la sociedad civil afines a las clases dirigentes) 
en el marco de una serie de políticas de homogeneización implementadas que tienen como fin la conformación de un imaginario nacional en un contexto marcadamente heterogéneo. Dicho en otras palabras, las diversas modalidades diccionarísticas devienen, cada una a su modo, un lugar privilegiado de construcción y de representación, tanto de la unidad de lengua como de la relación lengua / nación / Estado ${ }^{11}$. Constituyen, a nuestro entender, parte de lo que Oszlak (1997) denomina los mecanismos de penetración ideológica en la medida en que actúan como aparatos de acción política decididos y efectuados desde el Estado en tanto instancia modeladora de la sociedad. Conforman un gesto de afirmación de lo nacional, característica que comparten con otras discursividades como las gramáticas, las obras literarias, los relatos históricos y los manuales escolares.

En la medida en que el proceso de formación y consolidación del Estado nacional argentino se desarrolló en un largo período, podemos localizar en su derrotero diferentes momentos históricos. Ahora bien, en lo que concierne al proceso de diccionarización, Nunes ${ }^{12}$ afirma que las diversas etapas históricas se relacionan con diferentes formas diccionarísticas. En otras palabras, toda transformación histórica implica inevitablemente cambios en la lengua. Y es, justamente, en el nivel del léxico donde más se reflejan los cambios socioculturales. De ahí, entonces, la necesidad de producir en momentos de grandes cambios nuevos instrumentos lingüísticos, en particular diccionarios, para dar cuenta de préstamos, neologismos, cambios de sentido de ciertas voces, entre otros aspectos. Estas últimas ideas expuestas nos conducen a

11 Creemos que esto se produce a partir de un doble movimiento: por un lado, los diccionarios procuran legitimar el léxico argentino y afirmar la identidad lingüística nacional (la identidad del español de la Argentina), por lo menos en ese nivel, y, por otro, buscan estructurar y estabilizar (poner en orden) el universo social fuertemente diverso, estableciendo y regulando, por ejemplo, los significados legítimos de ciertos términos.

12 Los trabajos de Nunes (2001, 2002, 2003, 2006a, b y c, 2007 y 2008) representan un antecedente fundamental para nuestro trabajo. En particular, el autor se concentra en la historia de la constitución del diccionario monolingüe en Brasil: presenta los momentos del proceso de diccionarización en un arco temporal que va del siglo XvI al xx (relatos de cronistas, diccionarios bilingües, diccionarios monolingües, diccionarios complementarios, diccionarios de términos técnicos, diccionarios de brasileirismos, diccionarios generales, entre otros) y analiza las condiciones de producción, teniendo en cuenta los siguientes factores: territorialidad, administración del territorio, urbanización, institucionalización, contactos lingüísticos, identidad nacional, influencia de teorías filosóficas y lingüísticas y la aparición de las nuevas tecnologías. De esta manera, lee el diccionario con el objeto de observar y comprender el modo cómo se producen sentidos en ciertas coyunturas, teniendo en cuenta su materialidad discursiva (por ejemplo, contrasta las obras producidas en el período colonial con las del período imperial). Es decir, analiza no solo la función del diccionario sino también su funcionamiento. 
concebir y, por extensión, a analizar el diccionario como un instrumento discursivo, histórico e ideológico. Discursivo, porque como dice Orlandi (2002: 103): "La lexicografía discursiva ve, en los diccionarios, discursos. De ese modo, $[\ldots]$ podemos leer los diccionarios como textos producidos en ciertas condiciones. Así, su proceso de producción se vincula con una determinada red de memoria $(\ldots)^{13}$ ". Histórico, porque el diccionario no debe ser tomado independientemente de las condiciones socio-históricas de producción en las que se genera. En efecto, los diccionarios de distintas coyunturas traen referencias sobre la sociedad y el modo de vida de la época ${ }^{14}$. Ideológico, porque el diccionario como discurso proyecta una representación concreta de la lengua, en la que se pueden encontrar indicios del modo cómo los sujetos -como seres histórico-sociales afectados por lo simbólico y por lo político bajo el modo del funcionamiento de la ideología ${ }^{15}$ producen

13 Nunes (2006a: 18) señala: “(...) el diccionario es producto de prácticas ejercidas en determinadas coyunturas. De ahí que (...) para su análisis es preciso conocer sus condiciones de producción. Como todo discurso, el diccionario tiene una historia, construye y actualiza una memoria, reproduce y desplaza sentidos, inscribiéndose en el horizonte de los decires históricamente constituidos". Como espacio de la memoria discursiva, el diccionario activa y silencia distintas memorias (se construye en un vaivén continuo entre el recuerdo y el olvido). Los conflictos históricos dejan, así, sus vestigios sobre los sentidos producidos (continuidades y transformaciones) y sustentados socialmente como memoria materializada en la lengua. La producción lexicográfica es atravesada por distintas memorias discursivas y responde a distintas formaciones discursivas producto de las tensiones políticas, sociales e ideológicas de cada coyuntura histórica. Este enfoque permite ver cómo los sentidos de las palabras están en proceso, significan diferentemente de acuerdo con las diversas formaciones discursivas, que corresponden a distintas posiciones del sujeto de cara a la ideología. La manera de interpretar los vínculos entre el discurso lexicográfico y la sociedad se producen dentro de las formaciones ideológicas de cada época, con todos sus discursos y contradiscursos.

Algunas precisiones conceptuales: para Pêcheux (1975 [2009]), el interdiscurso es un complejo de formaciones discursivas, entre las cuales se establecen relaciones de alianza, de contradicción, de delimitación. Y la formación discursiva (noción desarrollada inicialmente por Foucault (1969 [2005]) y fundamental para la comprensión de las regularidades del discurso) "se define como aquello que en una formación ideológica dada -o sea, a partir de una posición en una coyuntura socio-histórica dada-determina lo que puede y debe ser dicho". Remite, por un lado, a las regularidades entre objetos, modalidades de enunciación, conceptos y elecciones temáticas y, por el otro, al sistema de reglas históricamente determinadas que las generan.

14 Realizamos una lectura crítica del diccionario que atiende fundamentalmente a su singularidad histórica. Singularidad histórica que se debe observar en su decir no solo a partir de sus repeticiones, reformulaciones y transformaciones sino también a partir de sus silencios. Todos ellos claramente significativos.

15 Dos de las metas interrelacionadas del Análisis del Discurso son: 1. descubrir, desentrañar en los discursos la ideología subyacente, no dicha y a veces en contradicción con la explicitada, y 2. revelar los mecanismos lingüísticos por los que se naturalizan posiciones que son, en realidad, ideológicas. 
lenguaje. Están abiertos a las "batallas ideológicas" en tanto instrumentos lingüísticos y en tanto artefactos discursivos (Orlandi 2002: 203).

En síntesis, el abordaje discursivo lleva no solo a comprender la historicidad de la producción de los sentidos, sino también a explicitar las relaciones sociales y los componentes coyunturales incluidos en la producción del diccionario. Es decir, solo un análisis discursivo puede situar ideológicamente los efectos del diccionario, observando, en su constitución, las formas materiales en tanto indicios de procesos discursivos e históricos ${ }^{16}$ : nos permite observar regularidades y desplazamientos de acuerdo con las distintas coyunturas. La adopción de una perspectiva glotopolítica, que conciba los diccionarios como gestos de intervención, por su parte, nos lleva a abordar tanto la incidencia que puedan tener los procesos políticos, sociales, económicos, culturales y tecnológicos en el discurso lexicográfico, como los modos en que se construyen las representaciones sobre el concepto de nación.

\section{LAS DISTINTAS MODALIDADES DICCIONARÍSTICAS}

En el caso argentino, las distintas condiciones que atraviesan el (largo) proceso de formación y consolidación del Estado nacional argentino (1870-1910) dan lugar al surgimiento y al desarrollo de cuatro formas diccionarísticas que buscan adaptarse y adaptar las diversas situaciones histórico-sociales que se imponen. Conviene aclarar dos aspectos importantes sobre esta cuestión: por un lado, que las diferentes modalidades no se apartan de modo tajante, sino que algunas (en realidad varias) de sus características son compartidas. Por otro, la relación entre el contexto y el diccionario no es ni mecánica ni automática: la exterioridad no se refleja en el diccionario ni tampoco es una relación lineal de causa-consecuencia, sino que se trata de un vínculo constitutivo y, a la vez, dialéctico que se puede observar en la materialidad lingüística del discurso lexicográfico. Por ejemplo, a través del

16 Nunes (2006a: 161) afirma: "El análisis discursivo del diccionario cuestiona las evidencias de los sentidos de las definiciones y se propone comprender los procesos históricos de constitución de esos diccionarios. El diccionario es considerado en nuestra sociedad un objeto de consulta. Es visto como una referencia y pocas veces se cuestiona si una definición es buena o es mala. Pero, al estudiar, por medio de un método lingüístico-histórico, el modo de producción de las definiciones, de la estructuración de los artículos, de la formación de una imagen de lengua, el diccionario se torna un objeto de análisis y con eso se muestran las especificidades de cada uno y las diferencias en relación con los otros". 
análisis de las operaciones de selección de la nomenclatura; de definición; de categorización gramatical; de marcación diatópica, diatécnica, diastrática, diafásicas, etc., propias de la práctica lexicográfica, puesto que establecen un orden en el lenguaje y en las prácticas lingüísticas.

\section{El diccionario de ruralismos de la década de 1870}

El proyecto político liberal de la primera mitad del siglo XIX, planteado y defendido por Sarmiento en numerosos textos y formulado también en las Bases y puntos de partida para la organización política de la República Argentina, de Alberdi de 1852, representantes ambos de la Generación del 37, de organizar el Estado nacional a partir de la idea de poblar el "desierto" argentino con inmigrantes europeos a fin de lograr el anhelado "progreso" material y espiritual, así como la modificación de las pautas culturales, económicas y políticas de la población nativa y, de este modo, modernizar la nación, comenzó a cobrar forma concreta en los últimos años de la década del setenta y en las primeras del ochenta durante la presidencia de Julio Argentino Roca, quien un año antes había dirigido la Campaña del Desierto, conquistando nuevas tierras al sur de la provincia de Buenos Aires que se integraron al territorio nacional. Asimismo, cabe recordar que en el año 1876, durante el gobierno de Nicolás Avellaneda, se había sancionado la Ley 817 de Inmigración y Colonización que promovía la llegada de extranjeros. Unos años después también se logró la federalización de la ciudad de Buenos Aires, cerrando con este hecho un período de profunda inestabilidad política y económica. En este contexto de "paz y progreso" comenzó, entonces, en el país una etapa de crecimiento vertiginoso (acelerado y desorganizado) en diversos planos. En lo relativo al aspecto demográfico, al cambiar el siglo, la mitad de los habitantes era de origen extranjero.

No obstante, el movimiento migratorio masivo que ingresó al país no satisfizo las expectativas de la dirigencia política porque -respondiendo a los mecanismos del sistema capitalista en expansión en el mundo en la segunda mitad del siglo XIX- se expulsaba mano de obra de las zonas más empobrecidas de los países centrales, mientras que los países periféricos productores de materias primas, como la Argentina, los recibían. De ahí que la mayoría de los extranjeros que arribaron a nuestras costas no eran de origen anglosajón, como se esperaba, sino que eran principalmente italianos y españoles, provenientes de las regiones más pobres de Europa. Estos inmigrantes llegaban al país con la esperanza (y la promesa) de recibir un terreno para trabajar. Sin embargo, esta situación no pudo concretarse debido a la estructura latifundista del país que impidió el reparto de tierras. En consecuencia, los contingentes inmigratorios se instalaron en las ciudades, 
especialmente en Buenos Aires y en la zona del litoral fluvial y de la pampa húmeda. Los centros urbanos, entonces, empezaron a revelar no solo las huellas del progreso y de la modernidad, sino también se manifestaron altos índices de superpoblación, hacinamiento, marginalidad y criminalidad.

El grupo político e intelectual de la época comenzó a ver con malos ojos, con temor y con desconfianza al inmigrante que, en muchos casos, fue estigmatizado. Este nuevo escenario social, producto del desmesurado e "inquietante" crecimiento demográfico urbano, hizo reaccionar a las clases dirigentes que vieron fuertemente amenazada su hegemonía social, política y económica. Esta situación derivó en la implementación de políticas que intentaron garantizar la regulación y el control de la sociedad. Mejor dicho, este descontento de la elite criolla aparece así directamente asociado, como señala Cibotti (2002), a la construcción de la nación argentina.

La dicotomía fundante del imaginario (liberal) nacional (ideas, valores, mitos políticos, sistemas normativos, según Devoto 2006), propuesta por Sarmiento, planteaba que la barbarie (representada por la vida en el campo y por sujetos sociales como los negros, los indígenas, los gauchos y las montoneras) debía dejar lugar a la civilización encarnada por la inmigración europea (no española) y las nuevas formas de urbanidad. Al ver que la inmigración, como ya mencionamos, no era del origen deseado y que, además, era proporcionalmente excesiva, se produjo un desplazamiento (y en el caso de los inmigrantes, una inversión) de dicha dicotomía, asociada nítidamente al problema de la identidad nacional. Se inició, así, lentamente como reacción un proceso de revalorización e idealización de la figura del gaucho y de la vida campesina como ícono de la tradición y de un pasado mítico por parte de sectores nativistas y, como dice Devoto (2006), precursores del nacionalismo cultural de las primeras décadas del siglo xx. De este modo, se ponderaron los valores preinmigratorios y se pasó a demonizar el progreso y la inmigración en tanto irrupciones destructivas de lo autóctono ${ }^{17}$.

Numerosos investigadores de diversas áreas disciplinares coinciden en aseverar que el proceso que deriva en el desplazamiento de los términos de la oposición dicotómica sarmientina fundante del ideario nacional hegemónico tiene lugar a partir primordialmente de 1880 y alcanza su máximo punto de condensación en el Centenario (Altamirano y Sarlo 1980 [1983]; di Tullio 2003; Ennis 2008; Onega 1982; Prieto 1988; Rubione 1983 y Terán 2000).

7 Los indios, los negros y las montoneras no fueron afectados por el desplazamiento de la dicotomía fundante del imaginario nacional ya que quedaron excluidos y calificados como bárbaros y salvajes. 
Sin embargo, nosotros advertimos en el Diccionario de Argentinismos de la Academia Argentina de Ciencias, Artes y Letras (1875-1879) ${ }^{18}$ huellas de este proceso. Para demostrar esta idea, presentamos evidencias a partir del análisis del discurso lexicográfico, atendiendo tanto a la nomenclatura como a la microestructura en tanto efectos de discurso.

En el caso específico de la macroestructura, resulta interesante analizar qué campos léxicos se privilegian (y cuáles se excluyen), ya que dichas listas se relacionan con las discursividades puestas en juego en cada coyuntura histórica. Como resultado de la lectura de la lista de voces correspondiente a la letra A, colegimos que en el Diccionario de Argentinismos predominan los sustantivos vinculados con los mundos de la flora, la fauna, la alimentación y las prácticas, los hábitos y las costumbres de la vida rural. Luego de un análisis más minucioso de la misma lista de vocablos discernimos la preeminencia de un campo principal: el que se vincula con el mundo del

18 La Academia Argentina de Ciencias, Letras y Artes se fundó en Buenos Aires el 9 de julio de 1873 y tuvo una destacada vida activa hasta su cierre en 1879. La institución surgió por iniciativa de un conjunto de intelectuales, científicos y artistas pertenecientes a la elite porteña (entre sus miembros se encontraban el dramaturgo Martín Coronado (quien actuó como presidente durante casi todo el período de vida de la Academia), el científico y escritor Eduardo Holmberg, el poeta Rafael Obligado y el polígrafo Ernesto Quesada. Tuvo como propósitos estudiar tanto la cultura nacional en sus diferentes manifestaciones (lengua, literatura, teatro, pintura, música, escultura) como las ciencias (derecho, historia, geografía, zoología, botánica). La Academia contó con un reglamento interno cuya función fue delinear su modo de funcionamiento y sus actividades: "Artículo 1. La Academia Argentina tiene por objeto estudiar, protejer y difundir en la República las ciencias, las letras y las artes". En este sentido, la lengua era solo una de las áreas de interés. No obstante, el estudio del idioma, en particular del léxico, adquirió protagonismo puesto que uno de sus principales proyectos fue la preparación de un Diccionario de Argentinismos: "Artículo 3. Es un deber primordial de la Academia redactar un Diccionario de Argentinismos, y ocuparse constantemente del estudio de esta obra (...)” (p. 335). Es más, en el capítulo correspondiente a las facultades atribuidas a la Junta Directiva se enunciaba: "Artículo 20. Son atribuciones de la Junta Directiva: $1^{\circ}$ Dirigir la redacción del Diccionario de Argentinismos y de toda obra de la Academia (p. 337)". Las tareas para la realización del diccionario comenzaron en 1875. Puesto que las actividades se disolvieron abruptamente cuatro años después, el Diccionario quedó, en consecuencia, inconcluso. Sin embargo, contamos con una serie de textos: el "Reglamento de la Academia Argentina" de 1873, los "Principios a que debe ajustarse la redacción del Diccionario del lenguaje argentino", escrito por una comisión integrada por Obligado, Holmberg y Atanasio Quiroga, que establecía un conjunto de criterios y de normas cuyos fines eran la selección de la macroestructura y el tratamiento de la microestructura. Además, poseemos pasajes de correspondencia entre miembros activos (de número) de la corporación y académicos correspondientes (del interior del país) que colaboraban en la elaboración de la obra; fragmentos de artículos publicados en la revista El Plata Literario, que funcionaba como el órgano de comunicación informal de la Academia; memorias y actas institucionales y una considerable cantidad de asientos lexicográficos. Se cita por la edición de Barcia 2006. 
campo, específicamente el que se limita al ámbito pampeano y litoraleño. Así, la información que nos brindan los datos numéricos es la siguiente: la letra A consta de 91 entradas, de las cuales alrededor de 30, una tercera parte, se asocian con las costumbres de la vida del campo y especialmente del gaucho: acacharpado, accionero, achura, achurador, agarrada, aguachaje, ahijuna, alabancioso, alambrado, alambrar, albardón, alfa, alfajor, alzado, alzarse, amalaya, ancudo, apero, aplastarse, apoyar, apoyo, arreada, arreado, arriar, asidera, azote, azotera. Los argentinismos se confinan predominantemente al medio rural. Podemos reescribirlos, por ende, como ruralismos. Si proyectamos lo que sucede en la letra A al resto del diccionario, confirmamos que a lo largo de la obra prevalecen notoriamente los ruralismos: boleadora, chiripá, facón, lazo, mordaza, paisano, rancho, recado, tirador, entre tantas otras voces. Como vemos, se efectúa una operación que consiste en colocar la figura del gaucho y de sus costumbres en un primer plano. Por metonimia, entonces, la vida del gaucho y sus hábitos, en tanto elementos típicos, tradicionales de nuestro país, representan lo peculiar, lo particular, lo argentino. O sea, el gaucho se convierte en el lugar mítico de lo genuinamente local y valedor principal de la identidad nacional. Se privilegia, así, la vida del campo por sobre la de la ciudad y las prácticas del pasado por sobre las del presente. El estudio de la macroestructura revela un cambio en la orientación política liberal. Hay un desplazamiento de esta tendencia, que provoca un movimiento hacia una vertiente tradicionalista en relación con los procesos de modernización que se estaban desarrollando en el país.

Pasamos a continuación a la microestructura, con el fin de explicitar una serie de regularidades lingüístico-discursivas de los enunciados definidores que coadyuvan a demostrar nuestra idea. Concebimos esas regularidades como huellas que las transformaciones políticas, económicas, culturales y sociales dejan ver en la forma material de las partes que componen los artículos lexicográficos. La mayoría de los artículos exhibe una disposición que responde a una naturaleza doble: por un lado, presentan información lingüística (clase de palabras, categorías morfológicas y gramaticales, contorno temático que restringe el ámbito de uso) y, por otro, despliegan un tipo de saber enciclopédico. En los términos de la práctica lexicográfica, se trata, entonces, de un diccionario de palabras (diccionario de lengua) articulado con un diccionario de hechos y de cosas (diccionario enciclopédico) (Auroux 2007). En lo que concierne a este segundo aspecto, la información vinculada más con la cosa que con la palabra, localizamos que al lema le siguen segmentos descriptivos y explicativos amplios. La secuencia descriptiva, de hecho, tiene un modo enunciativo determinado en el cual alternan en orden de aparición la indicación de los aspectos 
físicos de los objetos como, por ejemplo, la dimensión, que se describe en términos de varas (medida de longitud que se usaba en España con valores que oscilaban entre 768 y $912 \mathrm{~mm}$ ) y, por otro, se hace hincapié en la función instrumental (indicación de la finalidad, utilidad) a través de una secuencia predominantemente explicativa:

boleadora. s. f. Instrumento que usan los paisanos en sus faenas rurales y diversiones. Consiste en una huasca de una vara de largo en uno de cuyos extremos tiene una bola retobada en cuero de potro, llamada manijera; del otro extremo parten dos o tres ramales que sustentan otras tantas bolas, semejantes a la manijera, aunque de mayor volumen y peso: cuando estas son en número de tres se llaman Tres Marías. Las hay de hueso, de hierro y de madera con plomo. Usan los paisanos la boleadora tomándola por la manijera y haciendo describir círculos por sobre la cabeza; la arroja, de a caballo, a una distancia considerable, y con notable destreza logran casi siempre enredar las patas del potro a quien se dirige el tiro (p. 144) ${ }^{19}$.

chiripá. s. m. paño que usan los gauchos en vez de pantalón. Consiste en una pieza de tela de algodón o lana de dos y media o tres varas, más larga que ancha; uno de sus bordes menores lo pasan por la cintura, quedando abierto por delante como un delantal posterior; y lo ciñen a la cintura por medio de la faja; el borde libre o inferior lo pasan por entre las piernas, de atrás hacia delante y ciñen nuevamente de modo que puede considerarse como una bolsa por cuyos lados salieran las piernas, la parte inferior del chiripá suele llegar un poco más debajo de las rodillas (p. 174).

facón. s. m. Gran cuchillo que usan los paisanos, hecho de un pedazo de sable o espada, cuya empeñadura es generalmente de plata. Traculó sujeto a la cintura por medio del tirador o de la faja del chiripá y metido en una vaina de cuero frecuentemente con engarces de plata.

fr. pelar el $\sim$. Sacar el facón de la vaina en actitud de pelea (p. 199).

lazo. s. m. Cuerda de cuero crudo torcida o trenzada, cuyo largo varía entre veinte y treinta varas, de que se sirven los paisanos para enlazar y pialar. En una de sus extremidades tiene una argolla de hierro para formar la armada y en la otra, una presilla que sirve para asegurarlo en la asidera de la cincha.

19 En adelante, las citas del corpus reproducen la ortografía, la puntuación y el destacado de los textos originales; las negritas, por su parte, son nuestras. 
$\sim$ chileno. Lazo torcido.

fr. dar $\sim$. Correr hacia el animal que se ha enlazado para disminuir el tirón (p. 219).

mordaza. s. f. Trozo de madera de forma cilíndrica como de 1/3, rasgado en uno o ambos extremos. Empléanla los gauchos para sobar cualquier lonja de cuero.

(Esp. Instrumento que se pone en la boca de una persona para impedir el hablar) (p. 239).

rancho. s. m. Construcción rústica de barro, paja y madera que constituye generalmente la vivienda de los habitantes de la campaña; sus paredes laterales se construyen clavando en tierra postes (costaneras) de tres varas de altura, más o menos, guardando una distancia de dos varas uno del otro, en los cuales se fijan horizontal y paralelamente camas o listones para sujetar los chorizos de barro y paja que forman la pared; sus frentes (mojinetes), que terminan el triángulo isósceles, llevan un principal de madera, el cual sostiene la cumbrera; en esta descansa la parte superior de las tijeras, mientras su inferior desciende hasta las paredes y frecuentemente hasta formar los aleros; sobre las tijeras se colocan horizontalmente latas de sauce o caña que sirven para sujetar la paja quinchada que forma el techo.

rancho. s. m. v. g. 1. La casa-habitación del gaucho en el campo.

Albergue de techo de paja y paredes de barro, sin puertas para abrir y cerrar, teniendo sólo una abertura más o menos espaciosa.

2. Casa pequeña, pobre y sin comodidades (p. 283).

recado. s. m. 1. Bastos con cabezada de madera y alas de zuela.

2. Las piezas del apero que sirven para ensillar el caballo.

recado. s. m. Las monturas de los hombres del campo. Consiste en dos pequeñas lomillas o bastos que descansan al lado del lomo del animal, estando aquellos reunidos por medio de un cuero curtido y labrado que es de 11 o 12 centímetros sobre las costillas del caballo. La montura completa para subir del caballo (p. 285).

tirador. s. m. Larga y ancha faja de cuero que ciñe el chiripá o bombacha del hombre de campo que la lleva. Está formado de dos hojas con el cuero bien sudado o curtido, y en ellas, por medio de costuras verticales. Se hacen varios bolsillos o compartimientos y también las caprichosas pegando en ciertos espacios monedas de plata u oro, siendo otras mismas de esta clase las que sirven prendiéndolas en los ojales externos del tirador para sujetar a la cintura (Esp. adj. el que tira) (p. 305). 
Consideramos que la preocupación significativa por la producción de un saber enciclopédico, además del lingüístico, radica en la idea de revalorizar, traer al presente un elemento simbólico: los objetos y las costumbres que ya no están, que están siendo reemplazadas y perdidas y que es preciso no olvidar. El diccionario se muestra, así, como una fuente, un observatorio de saber enciclopédico, que sirve al conocimiento de la tradición. La imagen de la Argentina es la de un espacio rural que establece pocas (casi nulas) relaciones con el espacio urbano.

Otras regularidades que observamos en la microestructura del discurso lexicográfico del Diccionario de Argentinismos son el uso del tiempo verbal pasado y la presencia de marcas cronológicas como hist. (histórico) y ant. (anticuado) en ciertas definiciones vinculadas con campos semánticos asociados a determinados actores sociales, como, por ejemplo, los indios, los negros y las montoneras, refiriéndose, como vemos, más a la cosa, al objeto (y al sujeto) que a la palabra. Interpretamos estas huellas como producto de las nuevas condiciones sociales y políticas del país, en las cuales estos grupos no "encajaban". Constituyen, así, la alteridad "bárbara":

bozal. adj. Aplicábase a los negros que hablaban torpemente el castellano. Dícese en general de los extranjeros que lo pronuncian mal (p. 147).

contingente. s. m. Cierto número de soldados con que cada partido de campaña contribuía semestralmente para la defensa de las fronteras de Buenos Aires (p. 185).

enchalecar. v. a. Poner el chaleco a los locos furiosos para sujetarlos. 2. Poner el chaleco de cuero: género de suplicio usado por algunos caudillos en las guerras del Río de la Plata, que consistía en arrollar un cuero fresco a la caja del cuerpo, inclusos los brazos del reo a quien se quería dar la muerte exponiéndolo a los rayos del sol hasta perecer (p. 194).

lomo negro. s. $m$. ant. Designáronse así a los federales que dejaron de ser rosistas, en vista de la marcha política seguida por el tirano (p. 221).

mazorca. s. f. Sociedad del tiempo de Rosas que tenía por objeto degollar unitarios, azotar a las señoras desafectas al gobierno y hacer manifestaciones de simpatía al tirano. Llámese así porque su símbolo era una mazorca en señal de unión entre sus miembros. Los unitarios decían más horca porque era una sociedad de muerte y exterminio (p. 235).

mazorquero. s. m. ant. Miembro de la sociedad de la Mazorca (p. 235). 
Por otro lado, pero en la misma línea argumentativa, ciertos enunciados definidores son marcados por el discurso del rechazo étnico:

bagual. s. m. 1. Potro salvaje.

2. Redomón que aún conserva sus instintos salvajes.

3. Met. Ignorante, torpe.

4. Hist. Baguales: tribu de indios que habitaba las márgenes del Río de Areco, formando parte de una reducción a cargo de clérigos misioneros, según el P. Lozano en su Historia del Paraguay, R. de la P. y Tucumán. Tomo I, cap. VI (p. 139).

catinga. s. f. Olor de negro. Es voz portuguesa que del Brasil ha pasado a nuestro lenguaje (p. 160).

malón. s. m. Invasión súbita y armada de los indios pampeanos sobre las estancias fronterizas de la Provincia de Buenos Aires, con el objeto de robar.

Fr. pegar o dar un . Invadir súbitamente los indios (p. 225).

toldo. s. m. Habitación nómada de los indios salvajes. Toldería (p. 306).

A partir, entonces, de una serie de operaciones -uso del tiempo verbal pasado, presencia de ciertas marcas de frecuencia de uso- se estigmatizan física y moralmente ciertos grupos sociales. Es necesario su desplazamiento (su desaparición) debido a las nuevas formas de trabajo, de vida y de propiedad privada ${ }^{20}$ que se estaban organizando en el país en pro de la civilización. Estos grupos sociales representan el pasado, pero no aquel que se revaloriza, como en el caso del gaucho, sino el pasado bárbaro.

Por último, observamos que la perspectiva de clase que adopta la elite dirigente hace aflorar "los fantasmas" respecto de los nuevos sectores sociales, generalmente de origen inmigratorio ya que carecen de "elevación del espíritu" propio de las clases tradicionales. Una lectura de la macroestructura nos permite ver que, en cuanto a estos nuevos actores sociales producto de la ola de transformaciones que se estaban produciendo en el seno de la sociedad, solo se registran voces vinculadas con las distintas

20 “accionero. s. m. ant. El que tenía una acción para vaquear. Hist. El accionero obtenía la propiedad de todas las cabezas que recogía en los campos de propiedad pública. La abundante procreación del ganado cimarrón dio origen a numerosos acciones que pagaban un impuesto" (p. 127). 
razas y los nuevos tipos y grupos sociales y sus apodos. Nada se dice sobre sus costumbres, sus hábitos, etc.:

bachicha. adj. s. Napolitano, italiano perteneciente a la plebe (p. 139).

carcamán. s. m. Apodo vulgar que se aplica a los italianos en general y en particular a los genoveses. (Esp. Marit. Apodo que dan los marineros a un buque grande, malo y pesado, y en la costa de Galicia, de contrabandistas. Domínguez) (p. 156).

chirusa. s. f. Llámase así a la mujer vulgar, de escasa educación y de familia no conocida, que por su traje y maneras trate de asemejarse a las personas de distinción sin conseguirlo (p. 174).

chusma. s. f. Plebe, gente inculta (p. 178).

fanfurriña. s. m. Apodo despectivo que se da a los brasileños.

Fr. ser un $\sim$. Ser un cobarde con ínfulas de valiente (Esp. Enojo leve y pasajero) (p. 199).

gringada. s. m. 1. Reunión de gringos.

2. Acción o dicho propio de un gringo (p. 207).

gringo. adj. 1. Italiano.

2. Europeo. Se dice solamente hablando de personas (p. 207).

guarango. adj. Persona de palabras y modales incultos (p. 208).

macaco. s. m. Apodo con que el vulgo designa a los brasileros (Esp. Género de monos).

macaco. s. m. v. g. Cierta clase de mono.

2. Nombre denigrante que se da a los brasileños (p. 223).

Estas voces, muchas de ellas, producto de operaciones de transición semántica (bozal, carcamán, macaco), son términos -epítetos, apodos-que se comenzaban a emplear para denominar a los diferentes grupos sociales que se estaban formando en la Argentina y que, más adelante, adquirían sentidos negativos al límite de la xenofobia. Resaltamos, también, la categoría gramatical de los artículos: fluctúa entre una definición morfológica como sustantivo (en tanto sustancia) y en otros como adjetivo (en tanto estado). 
La consolidación del Estado nacional como unidad, estructura administrativa e identitaria en la Argentina requería, como es sabido, la clara y definitiva delimitación de sus fronteras políticas y geográficas con los países limítrofes. En ese contexto, se hacía, entonces, imprescindible la ocupación de los territorios sureños de la Patagonia, reclamados como propios durante décadas por Chile. Solamente una vez lograda la pacificación interior impuesta por el Estado unificado a partir de la presidencia de Bartolomé Mitre (1862-1868), se pudo concretar ese objetivo con el triunfo decisivo sobre los pueblos indígenas. Para el Estado nacional, las campañas de la llamada Conquista del Desierto de la década de 1870 significaron la apropiación de una importante cantidad de hectáreas. Esas grandes extensiones de tierras fiscales, expropiadas a los pueblos indígenas, fueron incorporadas a la Argentina. Según se había señalado en la Ley de Inmigración, esos territorios serían destinados al establecimiento de los colonos llegados de Europa. Sin embargo, fueron finalmente regalados, adjudicados o distribuidos por sumas irrisorias de dinero a familias vinculadas al poder político y militar, que habían o bien financiado o bien participado de las campañas. A nivel interno, el objetivo de las campañas fue el corrimiento de la frontera agrícola-ganadera hacia el sur del país a fin de aumentar las fuerzas productivas tanto para formar y consolidar el mercado nacional como para incorporar la región al desarrollo capitalista agroexportador. Asimismo, los indígenas sobrevivientes fueron tomados como mano de obra de dicho sector productivo. Este proceso histórico específico creó las condiciones de posibilidad para el surgimiento de nuevas prácticas lexicográficas. Básicamente comenzó a organizarse otro conjunto de producción diccionarística: de indigenismos y, ligado a ella, de regionalismos. Esta modalidad presenta aspectos distintivos que le confieren un carácter singular en el marco del proceso de instrumentalización de la lengua mediante diccionarios de la Argentina.

En el marco, entonces, de la Conquista del Desierto que implicó el brutal silenciamiento (violencia física y simbólica) de diversos pueblos indígenas y, por extensión, de sus lenguas, vemos un movimiento tendiente a atesorar con la idea de preservar ciertos elementos culturales de los pueblos originarios a modo de elementos constitutivos del patrimonio histórico y etnográfico nacional. Entre ellos, se comenzó a estudiar el material léxico en la medida en que dejó profundas marcas en las diferentes variedades del español americano. En este sentido, los indigenismos fueron fundamentalmente considerados como objetos de gran valor, de una valía preciosa y preciada debido a su condición de ser rastros de lenguas o bien muertas o bien en vías 
de extinción y poco estudiadas, es decir, pasaron a ser tratados como piezas de museo (reliquias) que se debían reunir, coleccionar y conservar.

Granada, en el prólogo de su Vocabulario rioplatense razonado (1889), describe la situación (y el porvenir) inexorable de las lenguas indígenas en los siguientes términos:

Á su luz puede hoy descubrir el movimiento generador que las informara, quien se proponga penetrarlo en una época en que, ya muy transfiguradas, necesarias y precipitadamente se van extinguiendo en torpes labios. Leves restos estropeados del quichua quedan aún en las provincias argentinas arribeñas del norte, del araucano en la Pampa, y del guaraní, más cercanos á su pureza originaria, en el Paraguay, muy corruptos y entreverados con el castellano, en Corrientes y Misiones. Hállanse estos residuos de las lenguas aborígenes en la precaria condición de dialectos destinados á desaparecer por completo en no larga serie de años (p. 36).

No obstante, "estos residuos" -señala el autor- permanecerían en la memoria del idioma castellano del Río de la Plata:

El idioma castellano (...) en cuanto al Río de la Plata atañe, guardará memoria del quichua y el araucano, y mucho más visiblemente del guaraní, en mediano caudal de elementos lexicográficos, unos recibidos por el solo uso y otros adoptados en atención á las ventajas ó conveniencias que ofrecían (p. 37).

A continuación, analizamos la nomenclatura de la obra de Granada. En primer lugar, observamos qué clase de palabras prevalece: se registran mayoritariamente indigenismos, relacionados con instrumentos y armas (macana, bola en todas sus acepciones), vestimenta (guavaloca), calzado (ojota), y comidas y bebidas (chicha). En un número menor, aunque, por cierto, considerable, aparecen también ruralismos vinculados con la vida en el campo (flora, fauna, geografía, hábitos y costumbres) de la región más que con el mundo urbano. Una vez más, entonces, en la dicotomía entre los espacios rurales y urbanos, la lengua encuentra un lugar determinado: el del ambiente campesino.

Por otro lado, es destacable analizar en la microestructura las escenas que se configuran. En el vocabulario de Granada, la mayor parte de los enunciados definidores de los nombres de los pueblos aborígenes aparecen formulados sistemáticamente en tiempo pasado como si de los sujetos afectados por dichos procesos no hubiera sobrevivido ninguno, estableciendo, así, fronteras nítidas entre acciones que se desarrollan en los planos del pasado y del presente. La imagen discursiva de los pueblos indígenas se presenta como ceñida a un tiempo pasado: 
abipón, na, adj. Dícese del indio cuya generación, dividida en varias parcialidades, habitaba el norte de la provincia de Santa Fe, junto al Paraná, corriendo el sur del Chaco. Ú. t. c. s. Perteneciente á dicha generación (p. 69).

auca, adj. Dícese del indio de una parcialidad, rama de los araucanos, que corría la Pampa en las cercanías de Mendoza. Ú. t. c. s. Perteneciente á dicha parcialidad (p. 93).

guaraní, adj. Dícese en general del indio cuya generación, diversificada en innumerables parcialidades, se extendía desde el río de la Plata hasta el Orinoco próximamente. Ú. t. c. s. Perteneciente á dichas generaciones (p. 231).

mocobí, adj. Dícese del indio de una parcialidad, terrible por su fuerza, que erraba por el sur del Chaco, de idioma parecido al de los abipones. Ú. t. c. s. Perteneciente á dicha parcialidad (p. 285).

pampa, adj. Dícese del indio cuyas diversas parcialidades, algunas de origen araucano, vagaban por la pampa austral, confinante con la Patagonia, entre el río de la Plata y la cordillera de los Andes. Ú. t. c. s. Perteneciente á dichas parcialidades (p. 305).

La descripción del enunciado definidor nos permite plantear dos niveles de análisis, esto es, marcar una división enunciativa en la que, por un lado, se indica el dominio de la denominación (el aspecto nominal) y, por otro, se presenta la descripción o definición propiamente dicha (el aspecto ligado con lo real). La primera, formulada en tiempo presente, a partir de la palabra "dícese" (en oposición a "decíase") da cuenta del empleo efectivo y de la vigencia de la voz. La segunda, expresada en tiempo pasado, caracteriza la parte del diferenciador o especificador (proposición subordinada adjetiva) del enunciado definidor. En ella se construye una escena pasada en la que los indios "vagaban", "erraban" por el también pasado desierto argentino ya conquistado por parte del Estado argentino. A propósito, es elocuente el artículo sobre el desierto incluido en el Vocabulario rioplatense razonado, puesto que los dos planos están en pasado:

DESIERTO. Decíase el Desierto á la pampa que enseñoreaban los indios salvajes, hoy ya definitivamente conquistada y reducida á la vida industrial. Comprendía quince mil leguas, por las que vagaban quince mil indios salvajes, siendo el teatro de sus habituales saqueos, las provincias circunvecinas Buenos Aires, Córdoba y San Luis, á cuyos hacendados tenían en sobresalto continuo. El año de 1879 cortáronse por la raíz tamaños males (p. 204). 
Empero, llama poderosamente la atención la presencia enunciados definidores en tiempo presente cuyos sujetos definidos son, paradójicamente, también los indígenas:

cholo, adj. En las provincias arribeñas de la Confederación Argentina, dícese del indio doméstico y del mestizo en especial si es muchacho ó joven. Ú. t. c. s. (p. 199).

chusma, f. Muchedumbre de familias de indios, excepto los hombres de guerra, ó sea, conjunto de mujeres, niños y viejos que componen una toldería o campamento de indios (p. 202).

ladino, na, adj. Dícese del indio que habla corrientemente la lengua castellana (p. 253).

toldería, f. Campamento de indios, donde tienen sus toldos (p. 374).

En el contexto inmediatamente posterior a la Conquista del Desierto, entonces, cuando la extinción del indio es considerada un hecho por las autoridades gubernamentales, en el inventario lexicográfico de Granada solo aparecen en tiempo presente las definiciones que muestran un indio adaptado, integrado (transformado por la lengua, la moral y el trabajo y, por ende, más próximo) a las condiciones de vida del "proceso civilizatorio", entre ellas, tener la cualidad de ser "doméstico" (por oposición a salvaje) y "hablar corrientemente la lengua castellana". Todo lo precedente resulta, en síntesis, en la construcción de una determinada visión del indígena en la que éste con el rasgo de "salvaje", "primitivo" constituye, según el discurso de la microestructura, un hecho del pasado (en la que se deja ver una suerte de narrativa histórica que da cuenta de sus costumbres). Contrariamente, el indígena "civilizado", el aculturado, se define en presente y puede, solo con esos rasgos, formar parte del imaginario nacional. Lentamente, entonces, va teniendo lugar el proceso de transformación del espacio geográfico "salvaje" (el desierto) al espacio administrado, de modo de absorber lo heterogéneo y la alteridad.

\section{Los diccionarios de barbarismos de la década de 1890}

Como ya señalamos, en el marco del proyecto político de los intelectuales de la llamada Generación del 37, el fomento de la inmigración europea representaba, ciertamente, uno de los pilares fundamentales para lograr la modernización del país. Ese plan de promoción de una política inmigratoria con el fin de modificar la composición y la distribución de la población se 
enlazaba y, a la vez, posibilitaba la idea de convertir el "desierto" en un espacio productivo desde el punto de vista económico. Varios investigadores coinciden en aseverar que el ciclo histórico -iniciado en la década del setenta del siglo XIX- fuertemente marcado por el arribo de contingentes inmigratorios provenientes de diferentes latitudes constituyó el hecho social más importante en la constitución de la Argentina moderna. En el plano de la lengua en particular, el movimiento migratorio masivo afectó las prácticas y reconfiguró el escenario lingüístico argentino. Para algunos gramáticos y docentes ejerció una influencia enormemente negativa dado que ocasionó corrupción y deterioro sobre algunos aspectos del uso del español.

En este contexto, la elite letrada observaba con recelo la presencia inquietante del inmigrante como nuevo y masivo sujeto social. Estas circunstancias particulares generaron que el proceso de diccionarización del español de la Argentina se viera afectado, desde luego, por la aparición de una nueva modalidad lexicográfica: los diccionarios de barbarismos ${ }^{21}$. Es decir, la elaboración y la publicación de instrumentos lingüísticos que asumieron un carácter claramente normativo o prescriptivo en la medida en que incluyeron y, por extensión, excluyeron ciertos usos lingüísticos en general y ciertos vocablos en particular, además de describir y calificar las divergencias léxicas entre el uso americano (en nuestro caso, el argentino) y el peninsular. En efecto, son obras lexicográficas que dan cuenta de barbarismos, de neologismos y de extranjerismos y censuran su uso, tomando como parámetro la norma del castellano de Madrid, es decir, siguiendo las pautas establecidas en el DRAE.

El tratamiento del otro como bárbaro y de la voz incorrecta o imprecisa como barbarismo, sabemos, tiene su origen documentado en la Grecia Antigua, donde se consideraba así a los pueblos que no hablaban la lengua griega. Lo más interesante es que la etimología del lexema "bárbaro" (extranjero [no griego], en griego) se vincula con los que no hablaban o hablaban extrañamente, puesto que no hablaban griego y, por lo tanto, no emitían más que ruidos, sonidos confusos e ininteligibles (para los griegos).

21 La aparición de los diccionarios de barbarismos emerge como respuesta y, simultáneamente, como defensa de la lengua maltratada por el elemento extranjero y su incidencia en los usos del castellano que se emplea en la Argentina. Junto con Di Tullio (2003: 102) consideramos que: "En efecto, la «cuestión del idioma» resultaba un terreno particularmente apto para expresar la alarma: el caos lingüístico, la babelización, la contaminación del español, la emergencia de jerigonzas ininteligibles, la irrupción de jergas plebeyas exigían una solución, reclamada también por los escandalizados gramáticos peninsulares. El poliglotismo y el cosmopolitismo pasan a ser sospechosos: había que volver a las fuentes de la lengua y la literatura españolas". 
En nuestro corpus, si bien es cierto que todas las obras registran lo que en una primera aproximación se pueden llamar barbarismos, un análisis más detenido nos permite ver diferencias en su definición y alcance.

Comenzamos por examinar los títulos. En el diccionario de Seijas aparece expresamente el lexema en cuestión "Diccionario de barbarismos cotidianos". En la presentación que sigue al título y a los créditos del autor, se define lo que se entiende por barbarismos: "impropiedades de cierta clase de gentes". Es interesante observar en el retome intradiscursivo a través de una operación de ampliación no solo el carácter negativo asignado a partir de la voz "impropiedades", lo que supone inevitablemente su contrario "propiedad", sino también, y más especialmente, la atribución de dichas impropiedades a "cierta clase de gentes". El "Diccionario de barbarismos argentinos y otros excesos de la misma nacionalidad" de Turdera restringe, con respecto a Seijas, el alcance del registro de barbarismos: se limita, con exclusividad, al caso de aquellos de origen argentino. El refuerzo del matiz negativo está dado por el núcleo del segundo constituyente de la frase coordinativa copulativa "excesos", que connota algo que sobrepasa, va más allá de la medida o de la regla. Análogamente a Seijas, el elemento "clases sociales" también explica el uso de barbarismos. En "Voces y frases viciosas" de Sánchez, la palabra clave es el adjetivo "viciosas", palabra que incluye los barbarismos así como también los neologismos y los extranjerismos. El sustantivo "vicio" alude siempre a la idea, en la misma línea argumentativa, de desviación, mal hábito, defecto, error. Por último, "Notas al castellano en la Argentina" es el título que, a primera vista, parece más descriptivo que prescriptivo. Sin embargo, la unidad léxica "notas" significa tanto "marca", "observación", "comentario", como así también "reparo o censura desfavorable que se hace de las acciones de alguien". Es, justamente, en este segundo sentido que interpretamos el título de la obra de Monner Sans. Además, el hecho de colocar el sintagma "en la Argentina" y no "de la Argentina" es significativo para nuestro gesto interpretativo. En efecto, el uso de la preposición "de" confiere a la expresión un aire de posesión, de existencia de un castellano propio de la Argentina. Por el contrario, la preposición locativa denota el lugar y el tiempo y, así, queda claro que se trata indiscutiblemente del castellano tal como se emplea en ese territorio en un determinado momento.

Ahora bien, nos interesa observar qué voces se incluyen (y, por extensión, cuáles se excluyen) en los respectivos inventarios. Para Seijas, los barbarismos son "execrables"; "manchas con que diariamente deslustran los inapreciables tesoros de nuestra habla sonora" (p. 3); "colgantes arrapiezos desgarrada la majestuosa vestidura de ese idioma" (p. 3); "errores" (p. 4); "ridiculeces indefinibles" (p. 6) y "palabras afrancesadas" (p. 6). Sobre los 
galicismos en particular (los extranjerismos más censurados), empleados principalmente, y aquí está la mención clasista, por "ciertos" miembros de la Generación del Ochenta afirma: “(...) van extendiéndose y vistiéndose con fachendosa casaca de buen uso, y que no pararán hasta hacer que en América se hablen ocho ó nueve idiomas bárbaros (...)" (p. 6) $)^{22}$. Turdera, en el prólogo, utiliza un nosotros inclusivo de extensión bien amplia que hace referencia a todos los argentinos, sin distinción de clase: "Creo, y no se achaque esto á alabanza, que los argentinos hablamos bastante mal el castellano". Y continúa: "En nuestro afán de destrozar el armonioso idioma de Quevedo, hemos llegado al delirio de los BARBARISMOS, es decir que en gramática observamos las mismas reglas que en política. Así están ambas" $(\mathrm{s} / \mathrm{p})$. Al rastrear la macroestructura de su obra vemos que se amonesta con regularidad la condición de criollas ${ }^{23}$ de algunas voces:

ALMOHADILLA. -Clava este alfiler en la almohadilla.

-No, querida coquetuela, donde lo clavará será en el acerico. Aunque le parezca a Vd. mentira, criolla de mi corazón (p. 9).

BARBIJO. Es una palabra muy criolla y muy linda... que hay que suprimir de prisa y corriendo. En castellano se dice: barboquejo (p. 13).

REFALÓN. - ¡Cuidado con los refalones! Así hablan los compadritos. Las personas educadas dicen resbalón y no refalón (p. 30).

TRAIME. -iAh criollo! Dígase tráeme (p. 31).

El uso del voseo también marca el criollismo en tanto "exceso" de localismo:

ARRIMATE. -Dígase arrímate.

El hacer llanas las voces esdrújulas es una manía que puede llamarse argentina (p. 10).

DECIME. -iGauchito! Se dice dime (p. 18).

22 Además de los destinatarios extranjeros a quienes van dirigidas las críticas, en los discursos observamos una separación entre dos órdenes: por un lado, los que detentan el poder y, por otro, los que dominan la lengua legítima (Bourdieu 1985). La crítica de los diccionarios de barbarismos parte del segundo grupo y actúa también sobre el primero a los que, en algunos casos, acusa de "bárbaros", ya que constituyen el otro amenazante que hay que combatir en cuestiones lingüísticas.

23 La polémica en torno al criollismo en la lengua y en la literatura nacional llegó a su punto más álgido alrededor del año 1900, luego de la publicación de Idioma nacional de los argentinos, de Lucien Abeille. 
En Voces y frases viciosas, se define el término barbarismo como:

(...) ofrecemos (...) dos mil abortos ó dichos ridículos, que en el día le conviene extirpar del libro, del periódico, de la correspondencia epistolar y de la conversación, empleando en cambio las correcciones que se indican (p. 4).

Por último, Monner Sans define el barbarismo, en los siguientes términos:

¿Quién ignora que el barbarismo es un vicio que consiste no sólo en escribir o pronunciar mal las palabras, sino en dar a las castellanas un significado que no tienen, o emplear vocablos de otros idiomas, reemplazando con ellos los genuinamente españoles? (p. 47).

Y, más adelante, especifica:

(...) quizás aquí [en la Argentina] más que en parte alguna de América se barbariza en materia de lenguaje, y fue el vicio en aumento porque a su propagación han contribuido las causas siguientes: $1^{\mathrm{a}}$ la inmigración; $2^{\mathrm{a}}$ la incesante lectura de obras francesas; $3^{\mathrm{a}}$ los malos traductores; $4^{\mathrm{a}}$ y una mala entendida independencia de la autoridad académica (p. 47).

Los barbarismos son reformulados a lo largo del prólogo como "dislates", "vicios lingüísticos", "rudos golpes", "conversaciones arlequinadas con retazos de diversos idiomas" y "crímenes lingüísticos". La nomenclatura está compuesta de neologismos y de nuevas acepciones, así como de extranjerismos. Además, reciben notas algunos barbarismos por "vicios" en la escritura y en la oralidad:

Acostáte. -Por acuéstate, primo hermano de andáte y parientes, ambos, de los barbarismos vení, decí, bebé, tomá, etc. por ven, di, bebe, toma.

En todas estas palabras el imperativo pierde la $d$ de la segunda personal del plural y en acostáte, apretáte, venite, agrega el pronombre te del singular. Consecuencia normal del voseo (p. 63)

Apretáte. -Por apriétate, barbarismo grosero que aun se oye en bocas cultas.

Véase lo dicho respecto de acostáte.

Isaza y Cuervo, al tratar de este verbo, demuestra con ejemplos el buen uso que hicieron siempre de él los hablistas (p. 89). 
Otra porción de la macroestructura la componen los galleguismos. Recordemos que los gallegos son la segunda comunidad, en número de inmigrantes, que arriba a la Argentina en esa época después de los italianos:

Corbina o curbina. -Por corvina.

Verdad que los gallegos escriben corbina; pero como los argentinos no son gallegos, debemos escribir corvina.

Dice la Real Academia que el indicado pez abunda en el Mediterráneo. También abunda por nuestras aguas oceánicas, y los aficionados aseguran que tan buena y sabrosa es la corvina pescada cerca de Málaga o Valencia como la recogida cerca de Mar del Plata (p. 142).

Dea. -Por dé, subjuntivo del verbo dar, dicen muchos por aquí, como dicen también en Galicia.

Aun cuando antiguamente se dijo dea por déme, dé usted, hoy ni los gallegos ni los argentinos que hablan bien añadirán una $a$ que la eufonía y el uso rechazan, como nadie dice naturalmente do por doy, forma regular la primera del presente de indicativo muy en uso en el siglo XVI (p. 161).

Enriedo dicen el gallego y el argentino... poco leídos.

Del substantivo enredo, que es la forma correcta, nacieron enredadera, enredador, enredar, enredijo y enredoso.

La epéntesis no debe en este caso sorprendernos, pues es lógica en labios de los que dicen diferiencia (p. 83).

Como observamos, en las obras con una clara intención normativa se proponen distintas definiciones para la idea de qué es un barbarismo $y$, en consecuencia, las nomenclaturas se arman de modo distinto. Sin embargo, en todos los casos, las críticas buscan generar inseguridad lingüística, principalmente en los sectores medios de origen inmigrante. En términos generales, podemos decir que en una época de la historia argentina caracterizada por la gran inmigración se observa como correlato una realidad lingüística heterogénea inédita en el país. Estas grandes transformaciones económicas, políticas y sociales inciden, en el plano del lenguaje, en la voluntad de actuar sobre él. En este período en particular, se destaca la enérgica decisión glotopolítica de regular, poner orden, establecer jerarquías claras con el fin de mantener la unidad y la pureza de la lengua en el mundo hispánico. Al mismo tiempo, se busca poner en el lugar social que "corresponde" a los distintos sectores. Esto es, se procura mantener, a través del aparato escolar y de los "guardianes del lenguaje" que instauran la norma lingüística mediante una compleja estrategia, la estructura de clases. 


\section{Los diccionarios de argentinismos del Centenario de la Revolución de Mayo}

En la primera década del siglo xx se registraron los índices más altos del saldo inmigratorio de la historia de la Argentina. Debido, entonces, al progresivo aumento de la diversidad lingüística, social y cultural, se incrementó sensiblemente la aparición de discursos -pertenecientes a diferentes géneros y de procedencias ideológicas diversas- en los cuales se reflexionaba sobre la nación, sobre la nacionalidad y sobre la identidad asociada a ella. En la medida en que la identidad lingüística es, de acuerdo con lo expresado por numerosos investigadores del nacionalismo, uno de los atributos en la definición y en la consolidación de la identidad nacional, aquella pasó de ser un tema importante a convertirse, entonces, en este período, en un tema privilegiado. Por tal motivo, se intensificaron las instancias planificadoras -tanto sobre el estatus como sobre el corpus de la lengua ${ }^{24}$ - a partir de la producción de instrumentos lingüísticos como gramáticas y diccionarios, de instrumentos pedagógicos como manuales escolares y antologías literarias o de la aparición de discursos glotopolíticos variados -ensayos, artículos periodísticos, polémicas parlamentarias, leyes- que señalaban fuertemente el vínculo lengua-nación. En lo que concierne específicamente a la producción lexicográfica monolingüe, en los albores de la celebración del Centenario, en plena euforia estatal, surgió un conjunto de diccionarios de argentinismos en los cuales prolifera la cuestión identitaria.

En relación con la modalidad anterior, se produce, en algunos casos, un significativo corrimiento del polo normativo hacia el descriptivo. Asimismo, entreveremos una tensión entre las posiciones de enunciación del sujeto lexicógrafo: algunas obras se posicionan desde un espacio de enunciación argentino, moderno, positivista, inclusivo de la heterogeneidad del cuerpo social, que tiene en cuenta las transformaciones sociales, económicas, culturales, políticas y lingüísticas derivadas del movimiento migratorio masivo. Otras, en cambio, se sitúan más cerca de una posición argentina, de corte nacionalista, afín a un hispanismo cada vez con peso más fuerte,

24 Calvet (1996 [1997]) distingue tres niveles de intervención imbricados entre sí. Por un lado, la planificación del corpus, que da cuenta de las decisiones que afectan a la materia lingüística, es decir, al código (el léxico, la gramática, la ortografía). Por otro, la planificación del estatus, que atiende a las intervenciones en la distribución de las funciones de las lenguas en una sociedad. Finalmente, las políticas dirigidas a la adquisición, que son medidas relacionadas con la enseñanza de la(s) lengua(s) dentro de una comunidad. 
que considera pernicioso tanto el cosmopolitismo como las nuevas manifestaciones lingüísticas criollo-inmigratorias ${ }^{25}$.

Comenzamos examinando, entonces, la conformación histórica de la nomenclatura. El proyecto del Diccionario de argentinismos de la Academia Argentina de la Lengua (AAL) ${ }^{26}$ recrea, a nuestro criterio, la tradición nativista iniciada por la Academia Argentina de Ciencias, Letras y Artes. Por lo visto en el corpus, esta institución pretende incorporar al DRAE principalmente ruralismos, esto es, voces vinculadas con el mundo del campo y con la vida del gaucho como símbolo de la tradición y de lo genuina y auténticamente nacional. La presencia del poeta de signo nativista Rafael Obligado en ambas instituciones justifica esta posición:

Artículo caballo recelador. Argentinismos conexos a) caballo retajado; b) retajo; c) caballo de retajo; d) manada de retajo; e) retajar.

Crítica y definiciones. La voz recelador y su definición son insuficientes para las necesidades y hechos de la vida argentina y de los países ganaderos del Plata. Llámase en la República Argentina retajo ó caballo de retajo, al operado con un corte que se hace en la parte media del miembro, suficientemente abierto para que la evacuación del semen se produzca allí, sin tocar la yegua (AAL, p. 181).

25 Ambas posiciones comparten ciertos presupuestos de base: la consideración de que la lengua es un símbolo fundamental de la nación y la defensa de una ideología lingüística monoglósica. Blanco (1986/7) distingue, dentro de lo que denomina nacionalismo cultural que adquiere fuerza con posterioridad a la conmemoración del Centenario, entre un nacionalismo democrático descendiente del sector cosmopolita, liberal y positivista (que confía en el progreso indefinido) de la elite letrada que, para dar cuenta de la identidad (lingüística) nacional, intenta lograr una síntesis entre lo tradicional y lo nuevo, lo argentino y lo extranjero y lo americano y lo hispano, por un lado, y un nacionalismo de elite que sanciona puesto que le causa alarma y rechazo todo lo preveniente del extranjero, incluso con actitudes xenófobas y que derivaría unos años más adelante en un nacionalismo político ultraconservador y de raíz hispanista en materia lingüística, por otro.

26 La Academia Argentina de la Lengua fue fundada en calidad de correspondiente de la de Madrid en 1910, como consecuencia de la intervención conjunta -y directa- de la monarquía española y de la RAE, en concordancia con un sector de la intelectualidad nacional hispanófilo, en el marco de los festejos por el Centenario y en un contexto de marcada visibilidad de emergencia de posiciones hispanistas. Esta institución quedó conformada, en principio, por quienes habían aceptado el diploma de académicos correspondientes desde finales del siglo XIX. El proyecto principal fue la elaboración de un Diccionario de argentinismos que pudiera aportar materiales, por un lado, para elaborar un Vocabulario hispanoamericano junto con las restantes academias correspondientes y, por el otro, para actualizar y enriquecer el repertorio léxico del $D R A E$. De esta forma, se concretarían sus dos finalidades: coleccionar y definir las voces locales para contribuir al léxico general, y promover una acción conjunta con la red de academias. Esta institución tuvo una vida efímera, disolviéndose al año siguiente de su fundación. 
En los otros diccionarios, en cambio, la distribución y conformación de la macroestructura es bastante disímil. A pesar de que hay diferencias evidentes entre las tres obras restantes, coinciden en desplegar un criterio más amplio en la inclusión de voces con respecto a las tres modalidades anteriormente descritas e interpretadas. Los tres diccionarios obedecen, a su modo, a los imperativos coyunturales del momento de su publicación caracterizada básicamente por el movimiento migratorio masivo, por un lado, y por el crecimiento urbano acelerado y los primeros e incipientes desarrollos industriales, por el otro.

El Diccionario Argentino de Garzón es el que más tiene en cuenta el impacto social (y lingüístico) de la inmigración. Dicho en otros términos, incorpora este fenómeno social de gran escala a la lengua, en particular al plano léxico. Se observa una amplitud de criterio para incorporar voces procedentes de distintos orígenes. Expresa la pluralidad y la heterogeneidad a partir de la introducción de extranjerismos y de neologismos en tanto voces que integran la realidad lingüística nacional:

Por otra parte, en un país cosmopolita como el nuestro, á donde afluye copiosamente la inmigración extranjera, -no como los bárbaros en el mediodía de Europa, sino como los portavoces pacíficos del progreso-con sus múltiples elementos de origen extraño que se entremezclan y se confunden con los nuestros por los vínculos de la amistad, de las relaciones comerciales y hasta de la familia, no es posible evitar la aclimatación de voces de otros idiomas, que, aun sin ser necesarias, se aprenden en ciertos centros donde no se conocen sus equivalentes castellanas con la frecuencia de oírlas nombrar (p. IX).

Varios son los puntos para destacar. Primero, que las voces extranjeras (esencialmente galicismos, anglicismos e italianismos), los préstamos ya aclimatados en algunos casos a las reglas del español, se asocian y, a la vez, contribuyen a la civilización y al progreso. Segundo, como consecuencia de lo anterior, se vinculan con referentes del mundo urbano e industrial más que rural (affiche, amateur, americana, attaché, ferry-boat, ravioles, remise). Tercero, no son considerados, bajo ningún punto de vista, barbarismos ni sus hablantes bárbaros:

Al principio comencé á formar un vocabulario de barbarismos; pero resultaron tantos y tan generalizados en el país (y me refiero al lenguaje de la gente culta), que empezó á repugnarme el nombre de barbarismos dado á este inmenso caudal de voces, entre las cuales hay un número no insignificante que corren también en las otras naciones de la América hispana. Veía en esto un desconocimiento de la ley ineludible y universal de la evolución de la lengua (p. v). 
En lo que concierne a los neologismos, las justificaciones son varias y están notablemente enlazadas con el tema de los extranjerismos:

Nuevo mundo reclama nueva lengua: nuevos objetos piden nuevos nombres, nuevas producciones, nuevos animales, nuevas plantas, nuevas cosas, nuevas riquezas, exigen nuevas voces. Las modas, los usos y las costumbres, las circunstancias, las situaciones de los hombres, los modos de vivir, que cambian con el tiempo y con el contacto de unos pueblos con otros, el desarrollo de las ciencias, de las artes y de las industrias, el progreso, en fin, trae también consigo aparejado el de la lengua $(\ldots)$ (

Empero, en otro orden de cosas, llaman la atención dos hechos: uno, la observación que se hace con respecto a los ruralismos "Quien crea que este vocabulario es del lenguaje gaucho estará en un grave error" (p. vi). Con esto, la obra de Garzón se distancia de la que estaba proyectando la AAL, reducida al ámbito del campo y del mundo del gaucho. Garzón incluye ruralismos (abajera, acionera, acollarar, apero), pero no es un diccionario solo de estos términos. Dos, en el prólogo nada se dice sobre si los indigenismos integran o no el inventario de voces. Sin embargo, la lectura de la nomenclatura (de la letra A) nos da la pauta de su inclusión, especialmente de palabras de origen guaraní y quichua, vinculadas con la flora y la fauna (abatí, acutí, aguará).

En el Diccionario de argentinismos, neologismos y barbarismos de Segovia es destacable señalar el particular tratamiento que se le da a la macroestructura. El diccionario se divide en varias secciones ordenadas alfabéticamente: "Castellanismos y neologismos"27, "Americanismos"28,

27 "Llamo castellanismos y neologismos á aquellas palabras que son conocidas y usadas así en América como en España, puesto que figuran en algunos diccionarios de la lengua, aunque mis definiciones difieran muchas veces de las en ellos consignadas, ó esos vocablos tengan, además, otras acepciones en Argentina" (p. 7).

28 "Americanismos, denomino á las voces que se usan generalmente en Hispano-América y no me consta que sean usadas en la Península y también á muchas voces de origen americano" (p. 7). 
"Argentinismos"29, "Voces extranjeras"30, "Estancia y campaña"31, "Tribus indígenas y sus lenguas" 32 , "Barbarismos" de la separación en distintos rubros, colegimos que los argentinismos en sentido estricto, para Segovia, derivan también de varias fuentes: acepciones distintas de palabras castellanas (neologismos), indigenismos, extranjerismos (únicamente aquellos que están adaptados al sistema del castellano) y ruralismos ${ }^{34}$ : "Mi trabajo tiende, desde luego, á la justificación de los argentinismos (...) ya porque responden á una necesidad ó importan un progreso, ya porque corresponden á voces análogas de otros idiomas neolatinos" (p. 11).

Finalmente, nos queda analizar cómo se configura la nomenclatura del Vocabulario argentino de Díaz Salazar. El principal destinatario de su obra es el inmigrante español que arriba a la Argentina. De ahí que el autor declare:

Para los españoles que lleguen á la Argentina libres de irrazonables prejuicios y de exagerado amor a todo lo nuestro, ha sido escrito este Vocabulario, en el que á pesar de su corta extensión, están todos los argentinismos que debe conocer el extranjero que no pretenda hacer estudios especiales de la lengua en uso aquí (p. 13).

¿Qué se incluye y qué se excluye, entonces, como argentinismo en esta obra? Básicamente tres tipos de voces: barbarismos (categoría que comprende

29 “(...) llamo argentinismos sensu stricto, á los vocablos de uso corriente en el Plata y acaso también en Chile, ó en la Argentina exclusivamente; pero que no me consta que sean empleados en otras repúblicas hispano-americanas" (p. 7).

30 "Á las voces extranjeras había que darles su verdadero significado, ortografía y pronunciación. He coleccionado unas 500 palabras, que no figuran en el Diccionario de la Academia; pero en Buenos Aires, que es una de las ciudades más adelantadas y cosmopolitas del mundo, se usan muchas más" (p. 8).

31 "Como la estancia y la campaña constituyen hoy por hoy, las primeras fuentes de riqueza de la Argentina, les he dedicado cuidadosa atención, suministrado noticias, que sería inútil buscar ó muy difícil hallar en otras fuentes, salvo quizá en tratados de agricultura ó ganadería" (p. 8).

32 "Las tribus indígenas, de quienes somos herederos forzosos y por la fuerza, tribus que van desapareciendo poco á poco, merecen bien un recuerdo. Doy además una breve noticia de sus lenguas, especialmente del guaraní, quichua y pampa, que son los idiomas indígenas que han enriquecido nuestro lenguaje. Todas estas lenguas serán mañana de un estimable valor para el estudio de la época precolombiana de los pueblos americanos" (p. 8).

33 "Al enumerar los barbarismos, prescindo, por punto general, de los que comete la plebe ignorante (...)" (p. 8).

34 La justificación de la inclusión de ruralismos se vincula menos con la revalorización de la vida del gaucho que con una cuestión más coyuntural como es la naturaleza de la economía argentina de ese momento, es decir, el modelo agroexportador. 
los extranjerismos adaptados al sistema lingüístico del castellano), las acepciones diferentes de ciertas voces castellanas y algunos neologismos (bañadera, barbijo, galera). Respecto de los primeros, sentencia: "Los barbarismos que se han españolizado en la Argentina, los hemos incluido como verdaderos argentinismos" (p.14). Y condena:

Aunque los argentinos son pródigos en el empleo de voces extrañas á nuestra lengua, especialmente de italianismos, galicismos y anglicismos, nosotros hemos eliminado todas aquellas voces ajenas que se usan aquí, como en España, conservando la ortografía y todos sus caracteres de vocablos exóticos (p. 14).

Por último, es importante señalar que en la dimensión programática no hay reflexión alguna sobre la inclusión de ruralismos e indigenismos en la formación de la nomenclatura. No obstante, la lectura atenta del lemario muestra su inclusión sin marca de uso y sin información etimológica, respectivamente. Dichas voces están, sin más, integradas en el caudal léxico del español que se emplea en la Argentina.

En suma, el principal desplazamiento frente a las modalidades anteriores radica en que la peculiaridad del léxico deriva de voces provenientes de fuentes diversas: confluyen aportes de lo antiguo y lo nuevo, lo nacional y lo extranjero, lo indígena y lo hispánico. El argentinismo ya no es el ruralismo, ni el indigenismo ni el barbarismo, es un "crisol", resultado de la diversidad social y lingüística de la Argentina de esos años.

Para terminar, analizamos un conjunto de artículos lexicográficos social y culturalmente significativos y sensibles a la coyuntura histórica abordada, lo que nos permitirá observar la carga ideológica e histórica del diccionario. Tal como esperábamos, en los diccionarios de argentinismos del Centenario se resaltan las definiciones vinculadas con el contexto rural. Sin embargo, observamos una importante diferencia en relación con las modalidades diccionarísticas anteriores en cuanto a que éstos ponen de relieve también y, en mayor medida, escenas definidoras urbanas y contemporáneas en contraste con el mundo del campo y las prácticas del pasado como modo de configurar la nación. Se evidencia nítidamente la preeminencia de escenas definidoras - enmarcadas en el espacio tiempo argentino- que señalan la emergencia de nuevas prácticas sociales y de nuevos sujetos sociales. Merece la pena ver cómo el proceso de modernización (urbanización, industrialización, avances técnicos sobre todo en el área de las comunicaciones y de los transportes) desarrollado desde fines del siglo XIX y encarado desde el Estado por la Generación del Ochenta, transformó radicalmente el panorama social, político, económico y cultural. En resumidas cuentas, insistimos con énfasis en la idea de que la contingencia histórica imprime sus huellas en los artículos 
lexicográficos. En particular, ponemos el acento en la presencia de ciertas marcas, particularmente de transición semántica (fig. ${ }^{35}$ y Por extensión ${ }^{36}$ ) que dan cuenta de cómo ciertas unidades léxicas vinculadas primariamente con el mundo del campo pasan a ocupar otros sentidos relacionados con otro espacio: el de la ciudad y lo que ella conlleva. Al mismo tiempo, se produce un desplazamiento de un significado básico concreto a uno más abstracto. En Díaz Salazar aparecen como "marcadas" ciertas definiciones de argentinismos vinculadas con el mundo rural. En los enunciados definidores se muestra con regularidad el sujeto de la escena "gente de / del campo". Estos artículos son claramente menos numerosos en relación con la cantidad total del caudal lexicográfico registrado:

¡Ahijuna! interj. Muy usada por la gente de campo. Es contracción de ¡Ah! hijo de una (p. 20).

Chiripá. s. m. Pieza de tela ó paño que usa la gente de campo en vez de los pantalones (p. 29).

Chuse. s. m. Alfombra ordinaria, que fabrica la gente del campo (p. 29).

Chuspa. s. f. Bolsillo de cuero que usa la gente del campo para guardar el tabaco ó el dinero (p. 29).

Estribo de capacho. El de cuero y cubierto que suele usar la gente de campo (p. 32).

Gato. s. m. Baile de parejas al que son particularmente aficionadas las gentes del campo (p. 34).

Guayaca. s. f. Especie de bolsa que usa la gente de campo para llevar el tabaco picado (p. 35).

Joaquina. s. f. Nombre que la gente de campo de Córdoba da al bacín (p. 38).

35 El sentido figurado, de acuerdo con Martínez de Sousa (1995: 309), es el "sentido en que se toman las palabras o frases cuando denotan idea distinta de la que corresponde al sentido recto".

36 El sentido por extensión, de acuerdo con Martínez de Sousa (1995: 308), es el "sentido que tiene una palabra o frase por ampliación de su significado recto u originario a otro concepto relacionado con él". 
Queremos resaltar dos aspectos en relación con este conjunto recortado, por supuesto, de definiciones. Por un lado, la relación que se establece entre "gente de campo" y la calificación peyorativa de "ordinario" para los objetos asociados con este sector social. Todo lo ordinario, lo rústico proviene del mundo rura ${ }^{37}$. Por otro, reparamos en el hecho de que hay una diferencia entre lo que fabrica / usa y cómo nombra la gente de campo a determinados objetos. A nuestro entender, la estrategia de explicitar el sujeto en el enunciado definidor obedece a la necesidad de dejar asentado que el léxico de la "gente de campo" no es, en absoluto, una metonimia del léxico de la nación, sino de una determinada (y cada vez más pequeña) porción de la sociedad.

En términos similares, analizamos un recorte de artículos -también de Díaz Salazar- que da cuenta de unidades léxicas asociadas, en un primer momento, exclusivamente con los mundos rural e indígena que pasan a tener un sentido figurado ${ }^{38}$ (y en algunos casos, además, familiar) al referirse o bien a tipos sociales o bien a objetos urbanos o a nuevas prácticas:

Achurar ó Achurear. v. a. Quitar la achura á un animal. || fig. fam. Causar á uno daño en sus bienes ó hacienda (p. 19).

Bagual, la. adj. Caballería de poco valor. U. t. c. s. \| fig. fam. Persona torpe ú ordinaria (p. 21).

Bolear. v. a. Aprehender animales arrojándoles las boleadoras á las patas ó al pescuezo. || fig. fam. Jugarle á uno una mala partida (p. 22).

Carona. s. f. Pieza del aparejo de una caballería que va debajo del basto. \| Andar con la carona ladeada. fr. fig. y fam. Equivalente á la española andar de capa caída (p. 24).

37 “Guarango, ga. Adj. Dícese de la persona que en sus dichos ó acciones es grosera, incivil, ó que no guarda los miramientos que pide la buena educación” (Segovia, p. 222).

“Guaso, sa. Adj. Dícese de lo concerniente al hombre rústico ó de campo. \| m. y f. En el Interior, hombre rústico, campesino. Sin cultura. || Grosero ó incivil en sus dichos, modales o acciones" (Segovia, p. 222).

"Incivilmente. Adv. De mod. De una manera incivil, inurbanamente, incultamente" (Segovia, p. 228).

38 Para que haya sentido figurado (a través de metáfora o metonimia) debe haber entre los dos significados una base asociativa, es decir, una asociación entre dos dominios conceptuales con diferencias mínimas. 
Gaucho. s. m. Hombre de la campaña, experto en las maniobras del lazo. || adj. Bravucón, pendenciero. || fig. fam. Resuelto, diligente (p. 34).

Macana. s. f. Especie de cachiporra que, como arma, usaban ${ }^{39} \operatorname{los}$ indios de América. || fig. fam. Cosa de poco valor. || Extravagancia, disparate. || Tontería. || Mentira, Exageración (p. 42).

Malón. Dar un malón. En su sentido recto, malón significa ataque inesperado de indios, pero en algunas provincias es muy corriente esta voz, empleada en sentido familiar, para designar lo que en España se llama Asalto, en sentido también figurado. Se da un malón cuando se ponen de acuerdo varias personas para presentarse, sin previo aviso, en una casa conocida para obligar al dueño á improvisar un baile (p. 42).

En los otros dos diccionarios -Garzón y Segovia- también se observa este pasaje de voces restringidas primaria o básicamente al ámbito rural que adquieren nuevos sentidos, sentidos figurados y que, así, amplían y recargan su significado:

ARREADA (de arrear), Extracción furtiva ó violenta de ganado ajeno. \| Por extensión, razzia de paisanos para destinarlos al servicio militar (Segovia, p. 155).

Bagual, LA. adj. Arg. Apl. al caballo ó yegua de poca estima, ó mañeros. Ú. t. c. s., y m. c. c. s. m. \|Arg. Dícese del caballo ó yegua que no son serranos (...), que no tienen como éstos los vasos duros y resistentes, por lo cual no pueden andar en los caminos ásperos y pedregosos de las sierras sin estropearse. Ú. t. c. s., y m. c. c. m. \| s. m. y f. fam. Arg. Por ext., dícese de cualquier caballo ó yegua. $\|$ adj. fig. y fam. Arg. Apl. al hombre ó mujer rudos ó flacos de entendimiento. Ú. t. c. s. \|f fig. y fam. Arg. Dícese de la persona torpe y ordinaria. Ú. t. c. s. (...) (Garzón, p. 45).

CHILludo, DA. adj. Arg. Que tiene chilla ó está cubierto de ella. Cabra chillada; cuero, pellón, chilludo (...) $\|$ fam. Arg. Por ext., dícese de las personas que tienen el cabello largo, lacio y cerdudo, ó el cuerpo cubierto de pelos de esta clase, y del mismo pelo ó cabello (Garzón, p. 154).

39 Es interesante notar, una vez más, el tiempo verbal pasado en el enunciado definidor. Como vemos, en estas obras persiste la idea de que los pueblos indígenas estaban en vías o directamente en extinción. 
Por otra parte, complementamos el análisis con los argentinismos de Garzón, Segovia y Díaz Salazar que, al definir la población argentina en estrecha vinculación con el par dicotómico mundo rural / mundo urbano, producen enunciados polarizados. Mientras que lo rural se asocia con lo ordinario, lo rústico y el pasado, la ciudad se coliga con la civilización y el progreso:

CHIRIPÁ. s. m. Arg. Manta ó tela de lana ó algodón, á veces de seda, de forma cuadrilonga, que usan nuestros paisanos en vez de pantalones: la introducen por entre las piernas, alzando uno de los extremos adelante y el otro atrás, hasta la cintura, y sosteniéndolos en ella con el tirador ó culero, ó con una faja, de modo que queden libres ó sueltas las cuatro puntas. Los calzoncillos que asocian al chiripá son muy anchos y llevan deshilados y flecos de adorno. || Arg. Manta que usan también nuestros campesinos y que se ponen alrededor del cuerpo á guisa de saya, sostenida en la cintura por el medio dicho. Este no se adapta, como el otro, para montar á caballo. (...) El avance de la civilización en la Argentina va suprimiendo ya esta prenda. Sin embargo, todavía se usa mucho en las provincias mediterráneas (Garzón, p. 157).

ESTAQUEAR. (De estaca.) v. a. Arg. Estirar y clavar con estacas un cuero fresco para que se oree. \|Arg. Atar y estirar á un hombre, por los pies y las manos, á estacas fijas en el suelo, poniéndole de boca sobre éste, ó en el aire; lo cual solía hacerse por castigo, particularmente en los cuarteles y campamentos; recuerdos, hoy, felizmente de una época de barbarie ya extinguida con los progresos de la civilización (Garzón, p. 200).

PACHIQUIL. s. m. Arg. Rollo de trapo ó hierbas que se ponen las mujeres sobre la cabeza para llevar en ella cosas pesadas, particularmente el cántaro con agua, y las lecheras el de leche. El progreso, que va desterrando poco á poco las cosas y las costumbres de otra época, ha sustituido estas vasijas de barro y el pachiquil por las cómodas cañerías de aguas corrientes y por los bruñidos y brillantes tarros de leche que ocupan como grandes señores un asiento distinguido en pintadas y vistosas jardineras (Garzón, p. 345).

PAYADOR. s. m. Arg. Trovador popular y errante, que canta, acompanándose en la guitarra, improvisando coplas, por lo regular á competencia con otro, ó de contrapunto, como vulgarmente decimos en este país, midiéndose entre ambos competidores su numen versificador en una especie de diálogo, en el que, con mucha frecuencia, suelen arrancar estruendosos aplausos de los circuntantes el ingenio y la agudeza de los cantores y la prontitud y espontaneidad con que el uno contesta victoriosamente á las chuscadas del otro. (...) El payador campesino, el 
payador guaso, bárbaro, que cantaba, en versos caldeados por la sangre generosa de las víctimas, á la santa federación, ha desaparecido ya, y sus ecos aguardentosos no volverán, por fortuna, á escucharse más; pero, como cada época tiene su tradición y los representantes que, en una ú otra forma, se esfuerzan en conservarla, hoy ha reemplazado en la escena á aquellos cantores de torvo ceño el payador urbano, cosmopolita, que canta sobre motivos más humanos, más nobles, más conformes con el estado de civilización que hemos alcanzado (Garzón, p. 364).

Tropa. s. f. Arg. Conjunto de carretas ó carros, con sus caballerías ó bueyes, destinados al trajín ó acarreo de géneros ó mercaderías, aun a largas distancias (...). $\|$ Arg. Estas mismas carretas ó carros cargados (...). $\|$ Arg. Conjunto de animales de carga que sirven para trajinar (...).\| Arg. Conjunto de estas acémilas con sus cargas (...). Estas travesías de tropas de mulas son muy frecuentes en las serranías de las provincias del interior, y antes de los ferrocarriles lo eran igualmente entre las de San Juan, Mendoza, La Rioja y Córdoba. \| Arg. Conjunto de animales del ganado mayor que se transportan de una parte á otra para el comercio (...) Veamos lo que eran, según don Domingo F. Sarmiento, las tropas de carretas en las vastas soledades de la Rep. Arg. antes que los ferrocarriles, el telégrafo y la libre navegación de los ríos trajesen á ellas esas corrientes de vida civilizadora, á cuyo impulso han surgido, en menos de medio siglo, millares de pueblos activos y florecientes, sustentados por el trabajo que multiplica fuerzas y riquezas (Garzón, p. 486).

La representación de la nación se manifiesta en la microestructura a través de tres procedimientos: uno, la explicitación del agente en los enunciados definidores; dos, la presencia de marcas de transición semántica (los usos figurados o por extensión) y tres, la definición mediante enunciados polarizados que se revelan por razón de la adjetivación con oposiciones rígidas del tipo ordinario, rústico, incivil, bárbaro frente a urbano, civilizado. Estos mecanismos lingüísticos que forman parte de la entrada lexicográfica expresan los ejes vertebradores de la configuración de la nación en el proceso de conformación y consolidación del Estado nacional argentino: las dicotomías campo / ciudad y barbarie / civilización y las connotaciones y desplazamientos que estas oposiciones suponen. 


\section{OBSERVACIONES FINALES}

En el presente artículo efectuamos una lectura del modo en que los diccionarios, en tanto textos que hablan sobre la lengua, exponen diversas representaciones de la nación. En particular, el estudio de una serie textual homogénea, desde el punto de vista genérico, como la de los diccionarios monolingües que registran la variedad argentina del español publicados en la Argentina y en el exterior entre los años 1870 y 1910 en el marco del proceso de construcción y de consolidación del Estado nacional, nos permitió observar las regularidades y los desplazamientos ocurridos debido a las transformaciones operadas en el espacio social.

La creciente modernización, acompañada de un movimiento de urbanización inmenso, el desarrollo de la industria, la afluencia inmigratoria masiva, la demarcación de los límites geográficos y políticos, el corrimiento de la frontera agrícola fueron acontecimientos históricos (y también lingüísticos y discursivos) que transformaron completamente la sociedad $y$, en consecuencia, dejaron sus huellas en la memoria lexicográfica. En nuestro caso, indagamos, desde la perspectiva glotopolítica cómo el discurso lexicográfico expresa con particular claridad la pretensión de intervenir, desde ciertos sectores sociales vinculados al Estado, en el espacio de la lengua: por un lado, en la configuración de un léxico nacional propio, y, por otro, en la conformación de un imaginario nacional.

En el largo trayecto analítico de examinar los discursos que describen e interpretan la relación lengua-nación en el proceso de diccionarización en la Argentina, confrontamos, desde el punto de vista diacrónico, diversas modalidades diccionarísticas: de ruralismos, de indigenismos, de barbarismos y de argentinismos. Para el análisis del corpus, concebimos menos el diccionario monolingüe como un objeto de consulta lingüística que un instrumento discursivo, histórico e ideológico. En ese sentido, el análisis supuso la remisión constante a las condiciones de producción socio-históricas con el fin de destacar ciertas zonas del discurso lexicográfico -llamadas dominios (prólogos, nomenclatura, microestructura)- más sensibles al contexto, entendiendo éste tanto en sentido estricto como amplio. Este modo de abordaje de los textos nos permitió, como ya dijimos, vislumbrar las continuidades y los deslizamientos, al tiempo que nos permitió también comprender la singularidad de cada modalidad diccionarística. 


\section{REFERENCIAS BIBLIOGRÁFICAS}

Altamirano, Carlos y Beatriz Sarlo. 1980. "La Argentina del Centenario: campo intelectual, vida literaria y temas ideológicos". En Ensayos argentinos. De Sarmiento a las vanguardias. Buenos Aires: CEAL, 1983, pp. 69-105.

Arnoux, Elvira Narvaja DE. 2000. "La Glotopolítica: transformaciones de un campo disciplinario". En Lenguajes: teorías y prácticas. Buenos Aires: GCBA, Secretaría de Educación, Instituto Superior del Profesorado "Joaquín V. González", s/p.

2006. Análisis del discurso. Modos de abordar materiales de archivo. Buenos Aires: Santiago Arcos.

2008. Los discursos sobre la nación y el lenguaje en la formación del Estado (Chile, 1842-1862). Estudio glotopolítico. Buenos Aires: Santiago Arcos.

Arnoux, Elvira Narvaja de y José del Valle. 2010. "Las representaciones ideológicas del lenguaje. Discurso glotopolítico y panhispanismo". Spanish in Context 7:1: 1-24.

Auroux, Sylvain. 1992a. A revolução tecnológica da gramatização. Campinas: Editora da UNICAMP.

1992b. "Introduction”. En Histoire des idées linguistiques, vol. II. Bruselas: Márdaga, pp. 11-64.

2007. "Listas de palavras, dicionários e enciclopédias. O que nos ensinam os enciclopedistas sobre a natureza dos instrumentos lingüísticos". Línguas e Instrumentos Lingüísticos 20: 9-23.

2009. "Instrumentos lingüísticos y políticas lingüísticas: la construcción del francés”. Revista Argentina de Historiografía Lingüistica I 2: 137-149.

Bertoni, Lilia Ana. 2001. Patriotas, cosmopolitas y nacionalistas. La construcción de la nacionalidad argentina a fines del siglo XIX. Buenos Aires: Fondo de Cultura Económica.

Blanco, Mercedes. 1986/7. "Las actitudes lingüísticas frente a la inmigración”. Cuadernos del Sur 19/20: 21-41.

Bourdieu, Pierre. 1985. ¿Qué significa hablar? Economía de los intercambios lingüisticos. Madrid: Akal.

Calvet, Louis-Jean. 1996. Las politicas lingüisticas. Buenos Aires: Edicial, 1997.

Сівотті, Ема. 2002. "Del habitante al ciudadano: la condición del Inmigrante". En Lobato, Mirta (dir.). 2002. El progreso, la modernización y sus límites (1880-1916), tomo V, Buenos Aires: Sudamericana, pp. 365-408.

Collinot, André y Francine Mazière. 1997. Un prêt à parler: le dictiónnaire. París: PUF.

Courtine, Jean-Jacques. 1981. "Analyse du discours politique (Le discours communiste addresé aux chrétiens)". Langages 62. Disponible en www.magarinos.com.ar/courtine. htm [Consulta 20/03/2010].

Del ValLe, José. 2007. "Glotopolítica, ideología y discurso: categorías para el estudio del estatus simbólico del español”. En del Valle, José (ed.). 2007. La lengua, ¿patria común? Ideas e ideologías del español. Frankfurt y Madrid: Vervuert / Iberoamericana, pp.13-29.

Devoto, Fernando. 2006. Nacionalismo, fascismo y tradicionalismo en la Argentina Moderna. México: Siglo XXI.

Di Tullio, Ángela. 2003. Políticas lingüisticas e inmigración. El caso argentino. Buenos Aires: Eudeba.

Ennis, Juan Antonio. 2008. Decir la lengua. Debates ideológico-lingüísticos en Argentina desde 1837. Frankfurt am Main: Peter Lang.

Foucault, Michel. 1969. La arqueología del saber. México: Siglo XXI, 2005. 
Guespin, Louis y Jean Baptiste Marcellesi. 1986. "Pour la glottopolitique”. Langages 83: 5-34. Guimarães, Eduardo y Eni P. Orlandi (orgs.). 1996. Língua e ciudadania. O Portugués no Brasil. Campinas: Pontes.

HaEnsCh, Günther. 1994. "Dos siglos de lexicografía del español de América: lo que se ha hecho y lo que queda por hacer". En Wotjak, Gerd y Klaus Zimmerman. 1994. Unidady variación léxicas del español de América. Frankfurt y Madrid: Vervuert / Iberoamericana, pp. 39-82.

Halperín Donghi, Tulio. 1982. Una nación para el desierto argentino. Buenos Aires: CEAL.

Lara, Luis Fernando. 1996. "Por una redefinición de la lexicografía hispánica”. Nueva Revista de Filología Hispánica, t. XLIV 2: 345-364.

Martínez de Sousa, José. 1995. Diccionario de lexicografía práctica. Barcelona: Bibliograf. 1997. Teoría del diccionario monolingüe. México: El Colegio de México.

Nunes, José H. 2001. "Léxico e Língua Nacional: Apontamentos sobre a História da Lexicografía no Brasil". En Orlandi, Eni (coord.). 2001. História das idéias lingüisticas: construção do saber metalingüistico e constituição da língua nacional. Campinas: Pontes, pp. 71-87.

2002. "Dicionarização no Brasil: condições e processos". En Nunes, José H. y Margarida Petter (orgs.). 2002. História do saber lexical e constitução de um léxico brasileiro. Campinas: Pontes, pp. 99-120. 11: 9-30.

2003. "Definição lexicográfica e discurso". Língua e Instrumentos lingüísticos

2006a. Dicionários no Brasil: análise e história do século XVI ao XIX. Campinas: Pontes.

2006b. "Nomenclatura de dicionário e redução da hiperlíngua brasileira". Histoire, Épistemologie, Langage 28/II: 63-84.

2006c. "Lexicologia e Lexicografia". En Guimarães, Eduardo y Mónica Zoppi Fontana (orgs.). 2006. Introdução às Ciências da Linguagem: A palavra e a frase. Campinas: Pontes, pp. 149-172.

2007. "Um espaço ético para pensar os instrumentos lingüísticos: O caso do dicionário". En Orlandi, Eni (org.). 2007. Política lingüística no Brasil. Campinas: Pontes, pp. 163-181.

2008. "Os diccionarios portugueses e a descolonização lingüística". Línguas e Instrumentos lingüísticos 20: 25-39.

Nunes, José H. y Margarida Petter (orgs.). 2002. História do saber lexical e constitução de um léxico brasileiro. Campinas: Pontes.

ONEGA, GLADYs. 1982. La inmigración en la literatura argentina (1880-1910). Buenos Aires: CEAL.

Orlandi, ENI. (1998): "Ética e Política Lingüística”. Línguas e Instrumentos lingüisticos 1: 7-16.

2000. Análise de Discurso. Princípios e procedimentos. Campinas: Pontes.

2002. Língua e conhecimiento lingüistico. Para uma História das Idéias no Brasil. San Pablo: Cortez.

2009. Língua Brasileira e Outras Histórias. Discurso sobe a língua e ensino no Brasil. Campinas: Editora RG.

Orlandi, ENi (coord.). 2001. História das idéias lingüisticas: construção do saber metalingüístico e constituição da língua nacional. Campinas: Pontes.

Orlandi, Eni (org.). 2007. Política lingüistica no Brasil. Campinas: Pontes. 
Orlandi, Eni y Eduardo Guimarães (comps.). 2002. Institucionalização dos estudos da linguagem: a disciplinarização das idéias lingüisticas. Campinas: Pontes.

Oszlak, Oscar. 1997. La formación del Estado argentino. Buenos Aires: Planeta.

PÊcheux, Michel. 1975. Semâtica e Discurso. Uma crítica à afirmação do óbvio. Editora da UNICAMP, 2009.

Prieto, Adolfo. 1988. El discurso criollista en la formación de la Argentina moderna. Buenos Aires: Sudamericana.

Rubione, Alfredo. 1983. En torno al criollismo. Buenos Aires: CEAL.

TERÁn, OsCAR. 2000. Vida intelectual en el Buenos Aires fin-de-siglo (1880-1910). Buenos Aires: FCE.

\section{FUENTES}

Barcia, Pedro Luis. 2006. Un inédito "Diccionario de argentinismos del siglo XIX”. Buenos Aires: Academia Argentina de Letras.

Díaz Salazar, Diego. 1911. Vocabulario argentino. Neologismos, refranes, frases familiares, etc. usados en la Argentina. Buenos Aires-Barcelona: Editorial Hispano-Argentina.

Garzón, Tobías. 1910. Diccionario argentino: Ilustrado con numerosos textos. Barcelona: Imprenta Elzeveriana de Borrás y Mestrés.

Granada, Daniel. 1889. Vocabulario rioplatense razonado. Segunda edición corregida, considerablemente aumentada, y á la que se añade un nuevo juicio crítico publicado por D. Juan Valera, individuo de número de la Academia española. Montevideo: Imprenta Rural, 1890.

Monner Sans, Ricardo. 1903. Notas al castellano en la Argentina. Buenos Aires: Ángel Estrada y Cía, 1944.

Obligado, Rafael. 1912. "Academia argentina de la lengua". Revista de Derecho, Historia $y$ Letras, t. LI: 224-228.

Quesada, Ernesto y Estanislao Zeballos. 1912. "A la Academia argentina de la lengua”. En Revista de Derecho, Historia y Letras, t. LI: 228-265.

SÁnchez, EnRiQue T. 1901. Voces y frases viciosas. Buenos Aires: Taller Tipográfico de la Penitenciaría Nacional.

Segovia, Lisandro. 1911. Diccionario de argentinismos, neologismos y barbarismos: con un apéndice sobre voces extranjeras interesantes. Buenos Aires: Coni.

Seijas, Juan. 1890. Diccionario de barbarismos cotidianos. Buenos Aires: Fidel y Cía. Limitada.

TuRdera, Juan. 1896. Diccionario de barbarismos argentinos y otros excesos de la misma nacionalidad. Buenos Aires: Juan Ribas Librero Editor.

Zeballos, Estanislao. 1912. "Fundación de la Academia Argentina de la Lengua". Revista de Derecho, Historia y Letras, t. LI: 177-182. 